
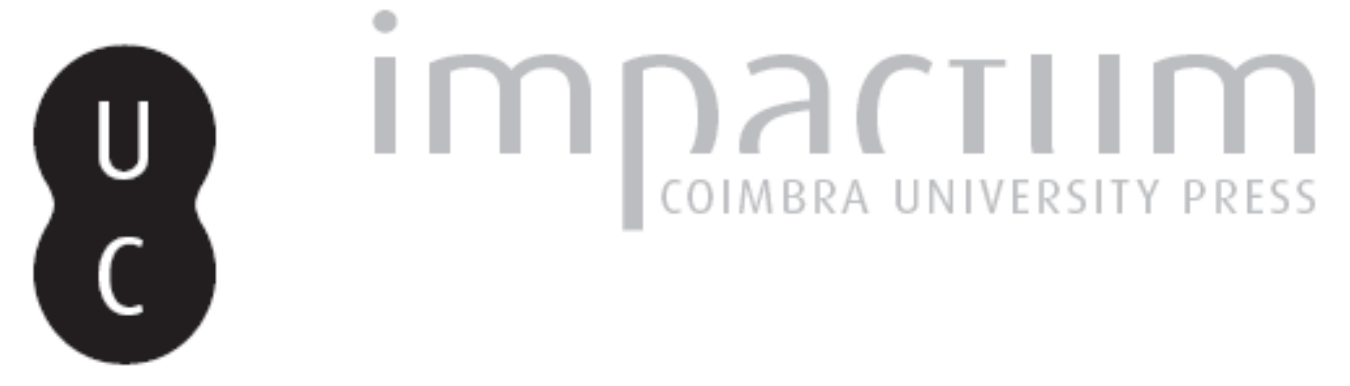

\title{
D. Álvaro de Castro (1. conde de Monsanto) perante os desafios da expansão portuguesa do século XV
}

\author{
Autor(es): $\quad$ Borges, Marco Oliveira \\ Publicado por: Centro de História da Sociedade e da Cultura \\ URL \\ persistente: \\ URI:http://hdl.handle.net/10316.2/39361 \\ DOI: \\ DOI:http://dx.doi.org/10.14195/1645-2259_14_3 \\ Accessed : $\quad$ 26-Apr-2023 06:41:38
}

A navegação consulta e descarregamento dos títulos inseridos nas Bibliotecas Digitais UC Digitalis, UC Pombalina e UC Impactum, pressupõem a aceitação plena e sem reservas dos Termos e Condições de Uso destas Bibliotecas Digitais, disponíveis em https://digitalis.uc.pt/pt-pt/termos.

Conforme exposto nos referidos Termos e Condições de Uso, o descarregamento de títulos de acesso restrito requer uma licença válida de autorização devendo o utilizador aceder ao(s) documento(s) a partir de um endereço de IP da instituição detentora da supramencionada licença.

Ao utilizador é apenas permitido o descarregamento para uso pessoal, pelo que o emprego do(s) título(s) descarregado(s) para outro fim, designadamente comercial, carece de autorização do respetivo autor ou editor da obra.

Na medida em que todas as obras da UC Digitalis se encontram protegidas pelo Código do Direito de Autor e Direitos Conexos e demais legislação aplicável, toda a cópia, parcial ou total, deste documento, nos casos em que é legalmente admitida, deverá conter ou fazer-se acompanhar por este aviso.

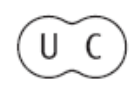




\section{4 \\ 2014}

\section{evista de História da Sociedade e da Cultura}

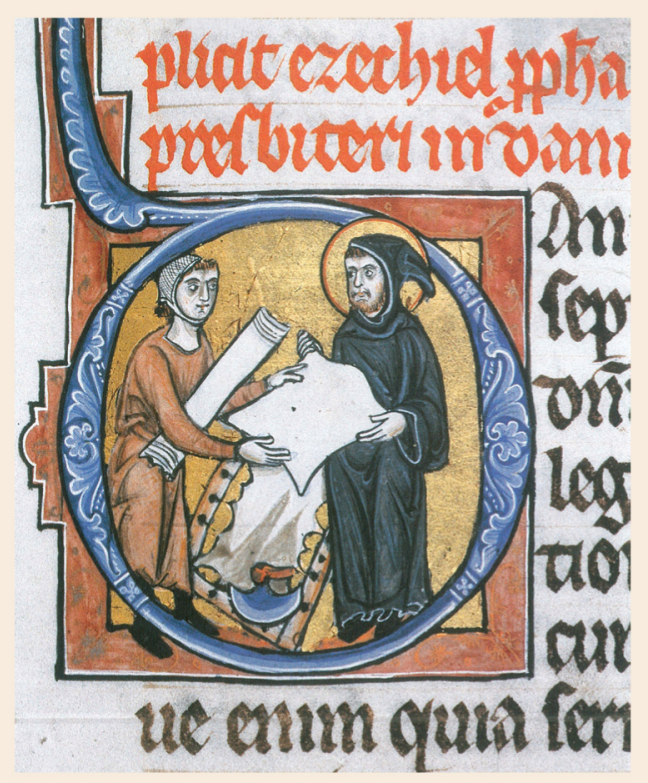

Centro de História da Sociedade e da Cultura Universidade de Coimbra 


\title{
D. Álvaro de Castro (1. ${ }^{\circ}$ conde de Monsanto) perante os desafios da Expansão Portuguesa do século XV
}

\author{
Marco Oliveira Borges \\ Centro de História, Universidade de Lisboa \\ Bolseiro de Doutoramento pela Fundação para a Ciência e a Tecnologia \\ marcoliveiraborges@gmail.com \\ Texto recebido em/Text submitted on: 15.06 .2014 \\ Texto aprovado em/Text approved on: 24.09.2014
}

\section{Resumo/Abstract:}

Neste estudo procuramos compreender de que modo D. Álvaro de Castro se envolveu nos desafios proporcionados pela expansão marítima portuguesa do século XV. Assim, para além de ser importante reter o seu envolvimento nas campanhas militares a Marrocos, não esquecendo também a sua actividade militar interna, há que tentar explorar a associação de D. Álvaro de Castro ao frete de navios com destino à Flandres e ao abastecimento de Ceuta.

On this study we try to understand in which way was D. Álvaro de Castro involved in the challenges brought up by the Portuguese maritime expansion of the $15^{\text {th }}$ century. Thus, although it is important to understand his involvement in the military campaigns in Morocco, as well as his internal military activity, it is also significant to try and explore his association with the vessel charter headed to Flanders and destined to the supply of Ceuta.

Palavras chave/Keywords:

D. Álvaro de Castro; Expedições militares; Marrocos; Frete de navios.

D. Álvaro de Castro; Military expeditions; Morocco; Vessel chartering. 


\section{Introdução}

O interesse por querer desenvolver um estudo alargado sobre D. Álvaro de Castro, camareiro-mor de D. Afonso V, conselheiro régio, senhor de Cascais, $1 .^{\circ}$ conde de Monsanto, fronteiro-mor e alcaide-mor da cidade de Lisboa (entre outros ofícios e títulos que foi acumulando), surgiu do próprio relevo que este fidalgo foi adquirindo no âmbito do desenvolvimento da nossa dissertação de mestrado ${ }^{1}$ e que já nos havia permitido elaborar um pequeno estudo de síntese envolvendo os seus feitos militares e actividade marítima ${ }^{2}$. Para além disso, o facto de não existirem estudos específicos sobre D. Álvaro de Castro, embora havendo importantes dados biográficos coligidos por alguns investigadores 3 , foi outro factor determinante para querermos aprofundar conhecimento sobre esta interessante figura da nobreza portuguesa quatrocentista que andou ligada a grandes acontecimentos da história nacional.

D. Álvaro de Castro (14??-1471) era filho primogénito de D. Fernando de Castro, governador da Casa do infante D. Henrique, alcaide-mor da Covilhã, 1. ${ }^{\circ}$ senhor do Paul de Boquílobo, senhor de Ançã e de S. Lourenço do Bairro, e de D. Isabel de Ataíde, filha de Martim Gonçalves de Ataíde, senhor de Monforte e alcaide-mor de Chaves ${ }^{4}$. Pelo primeiro casamento do pai tinha

1 BORGES, Marco Oliveira - O Porto de Cascais durante a Expansão Quatrocentista. Apoio à Navegação e Defesa Costeira. Dissertação de Mestrado em História Marítima (FLUL): 2012, passim.

2 BORGES, Marco Oliveira - "D. Álvaro de Castro", in DOMINGUES, Francisco Contente, SILVA, Jorge Moreira da e CASTRO, Tiago Machado (dir.) - Dicionário de História Marítima (2011), (http://ww3.fl.ul.pt/DHM/DHM/page3/page29/page29.html, consultado em 2012.06.22).

3 Cf. FREIRE, Anselmo Braamcamp - Brasões da Sala de Sintra, 2. ${ }^{a}$ ed., liv. terc., Coimbra, Imprensa da Universidade, 1930, p. 280-281; LOURENÇO, Manuel A. P. "História de Cascais e do seu Concelho", A Nossa Terra, 71 (1954) 2, embora sem indicar fontes e com algumas afirmações bastante discutíveis; ANDRADE, Ferreira de - Cascais - Vila da Corte. Oito Séculos de História. Cascais: Câmara Municipal de Cascais, 1964, p. 47-51 e 74; MORENO, Humberto Baquero - A Batalha de Alfarrobeira. Antecedentes e Significado Histórico, vol. II. Coimbra: Biblioteca Geral da Universidade, 1980, p. 758-763; SILVA, Joaquim Candeias e BRANCO, Manuel da Silva Castelo - A Beira Baixa na Expansão Ultramarina (Séculos XV-XVII). Subsidios históricos. Lisboa: Câmara Municipal de Belmonte, Comissão Nacional para as Comemorações dos Descobrimentos Portugueses, 1999, p. 167.

4 MORAIS, Cristóvão Alão de-Pedatura Lusitana (Nobiliário de Famílias de Portugal), t. II, vol. II. Porto: Livraria Fernando Machado, [s.d.], p. 110; SOUSA, António Caetano 
como irmãos D. Henrique de Castro, o qual fora eleito Prior do Crato mas morrera antes de tomar posse, D. Garcia de Castro, que combateu na batalha de Alfarrobeira integrando as hostes reais, D. Maria de Castro, 1. ${ }^{\mathrm{a}}$ mulher de D. Álvaro de Sousa (mordomo-mor), D. Isabel de Castro, condessa de Viana do Alentejo, por casamento com D. Duarte de $\operatorname{Meneses}^{5}\left(1 .^{\circ}\right.$ capitão de Alcácer Ceguer), e D. Catarina de Castro, condessa de Avranches, por casamento com D. Álvaro Vaz de Almada ${ }^{6}$. Do segundo casamento do pai, o nosso biografado tinha como irmãs D. Violante de Castro, senhora de Mafra, e D. Margarida de Castro.

D. Álvaro de Castro casou com D. Isabel da Cunha, filha de D. Afonso de Cascais e de D. Branca da Cunha, sendo D. Isabel neta do doutor João das Regras e legítima titular do senhorio de Cascais, apesar de D. Afonso continuar a usar o título de senhor de Cascais? ${ }^{7}$. Do seu casamento com D. Isabel, D. Álvaro de Castro teve como filhos D. João de Castro, 2. ${ }^{\circ}$ conde de Monsanto, D. Jorge de Castro, D. Joana de Castro e D. Leonor de Castro. Teve ainda, como filhos bastardos, D. Rodrigo de Castro ${ }^{8}$, D. Guiomar de Castro $^{9}$ (duquesa de Nájera) e D. Margarida de Castro $^{10}$.

de - Historia Genealogica da Casa Real Portugueza, t. XI, pt. II. Lisboa: Na Regia Officina Sylviana e da Academia Real, 1745, cap. II, p. 802-803.

5 MORAIS, Cristóvão Alão de - Pedatura Lusitana ..., cit., p. 111.

6 MORAIS, Cristóvão Alão de - Pedatura Lusitana..., cit., p. 110-111; MORENO, Humberto Baquero - A Batalha ..., cit., vol. II, p. 758.

7 D. Isabel recebeu o senhorio de Cascais a 31 de Maio de 1436, já depois da morte de D. Pedro da Cunha (seu irmão), ainda que sob tutela de seu pai, D. Afonso de Cascais, que continuava a assumir o título de senhor de Cascais (cf. Chancelarias Portuguesas. D. Duarte, vol. I, t. II. Lisboa: Centro de Estudos Históricos da Universidade Nova de Lisboa, 1998, p. 286-289, doc. 1024, p. 296-301, doc. 1032; MARQUES, A. H. de Oliveira - "Para a História do Concelho de Cascais na Idade Média - I", Novos Ensaios de História Medieval Portuguesa. Lisboa: Editorial Presença, 1988, p. 114-115).

${ }^{8}$ Combateu e foi ferido na batalha de Toro (PINA, Rui de - "Chronica do Senhor Rey D. Affonso V”, in Crónicas de Rui de Pina. Porto: Lello \& Irmão - Editores, 1977, cap. CLXXXVI, p. 840). Sobre esta batalha, vide ENCARNAÇÃO, Marcelo Reis da, A Batalha de Toro. Dissertação de Doutoramento em História (FLUP), 2 vols: 2011.

9 A mesma por quem Henrique IV, rei de Castela, veio a ter "amores" (GÓIS, Damião de-Crónica do Príncipe D. João. Lisboa: Universidade Nova de Lisboa, 1977, cap. XXXV, p. 87).

${ }^{10}$ MORAIS, Cristóvão Alão de - Pedatura Lusitana ..., cit., p. 112. Estas informações divergem de SOUSA, António Caetano de - Historia Genealogica ..., cit., t. XI, pt. II, cap. II, p. 806-807, que não refere D. Jorge de Castro e apresenta D. João de Castro, D. Joana de Castro, D. Leonor de Castro, D. Guiomar de Castro, D. Rodrigo de Castro e D. Madalena 


\section{D. Álvaro de Castro e a sua actividade militar em solo interno}

Não se sabe a data e local de nascimento de D. Álvaro de Castro, sendo que este fidalgo costuma ser confundido com um seu homónimo contemporâneo ${ }^{11}$. Porém, como não vem referido entre os combatentes que participaram na tomada de Ceuta, presume-se que, por essa altura, fosse muito novo ou ainda não tivesse nascido. Em todo o caso, D. Álvaro de Castro vai estar ligado a todas as outras campanhas militares a solo marroquino a partir de 1437 (Tânger), culminado em 1471 (Arzila), e a outros grandes acontecimentos da história portuguesa quatrocentista.

Ulteriormente à morte de D. Duarte, D. Álvaro de Castro vai estar presente nas Cortes de Torres Novas, iniciadas a 10 de Novembro de 1438, vindo a pertencer ao segundo giro do conselho régio com a obrigação de fazer cumprir o regimento do Reino que havia sido acordado ${ }^{12}$. Em 1439, aquando da crise suscitada pela morte de D. Duarte e a questão da regência do Reino, D. Afonso de Cascais, senhor daquela vila, optou pelo lado da rainha em vez do partido de D. Pedro. Posteriormente, a 29 de Dezembro de 1440, viu-se obrigado a deixar Portugal juntamente com o seu filho (D. Fernando de Cascais), exilando-se em Castela, vindo a morrer em Agosto

de Castro (em vez de D. Margarida de Castro) como filhos directos do casamento entre D. Álvaro de Castro e D. Isabel da Cunha.

${ }^{11}$ Existiram, pelo menos, dois homónimos de D. Álvaro de Castro seus contemporâneos. Um deles, enquanto fidalgo da casa do infante D. Henrique, também chegou a participar na expedição fracassada a Tânger, vivendo para lá do termo de vida do nosso biografado (cf. PINA, Rui de - Crónica do Rei D. Duarte. Lisboa: Editorial Presença, [1966], cap. XV, p. 100; FREIRE, Anselmo Braamcamp - “A honra de Resende”, in Archivo Historico Portuguez, vol. IV, n. ${ }^{\circ}$ 1-2. Lisboa: Officina Typographica - Calçada do Cabra, 1906, p. 30-31; MARQUES, João Martins da Silva-Descobrimentos Portugueses. Documentos para a sua História, vol. III. Lisboa: Instituto de Alta Cultura, 1971, p. 125, doc. 92; MORENO, Humberto Baquero - A Batalha ..., cit., vol. II, p. 757-758; DUARTE, Luís Miguel - Justiça e Criminalidade no Portugal Medievo (1459-1481). Dissertação de Doutoramento em História da Idade Média (FLUP), vol. I: 1993, p. 260 e passim; SILVA, Joaquim Candeias e BRANCO, Manuel da Silva Castelo - A Beira Baixa ..., cit., p. 167-168).

${ }^{12}$ Monumenta Henricina, vol. VI. Coimbra: Comissão Executiva das Comemorações do V Centenário da Morte do Infante D. Henrique, 1964, p. 270, doc. 96; MORENO, Humberto Baquero - A Batalha ..., cit., vol. II, p. 759. 
do ano seguinte ${ }^{13}$. Foi após a fuga do sogro que D. Álvaro de Castro passou a intitular-se senhor de Cascais ${ }^{14}$.

Por carta de 19 de Junho de 1441, assinada pelo regente, recebeu ordens para entregar o castelo do Crato (cuja alcaidaria detinha por ordem do infante D. Pedro) a D. Henrique de Castro, fidalgo da casa do infante D. Henrique ${ }^{15}$. Nesse mesmo ano, por carta de 18 de Agosto, foi nomeado para coudel da vila da Lourinhã durante um período de cinco anos ${ }^{16}$. A 1 de Setembro de 1443, D. Álvaro de Castro e sua mulher, D. Isabel da Cunha, venderam, por 400 dobras de "boom houro", umas casas situadas no Bairro dos Escolares $\left(\right.$ Lisboa) ${ }^{17}$ ao infante D. Henrique. Estas acabariam por ser destinadas ao Estudo Geral dessa cidade ${ }^{18}$.

A 11 de Abril de 1445, durante os preparativos de uma expedição a Castela, foi-lhe outorgada uma carta de privilégios em que todos os seus caseiros, lavradores, amos, mordomos e apaniguados ficavam isentos de impostos, de encargos concelhios e de servirem por terra e por mar $^{19}$. Em Maio desse mesmo ano D. Álvaro de Castro integrou a hoste comandada pelo jovem condestável D. Pedro que seguiu em auxílio do rei castelhano contra os infantes de Aragão, mas que não chegou a combater na batalha de Olmedo, ocorrida a 29 desse mês.

Ainda na regência de D. Pedro, por carta de 10 de Agosto de 1446, D. Álvaro de Castro foi nomeado para ir de armada em naus e navios com cavaleiros, fidalgos, escudeiros e outra boa gente a "alguns lugares que cumprem a nosso serviço", detendo para isso plena autoridade sobre

${ }^{13}$ PINA, Rui de - "Chronica do Senhor Rey...", cit., cap. XLI, p. 77-81; SOUSA, António Caetano de-Historia Genealógica ..., cit., t. XI, pt. II, cap. I, p. 784-785; FREIRE, Anselmo Braamcamp - Brasões da Sala de Sintra. Apres. e apênd. de Luís Bivar Guerra, [vol.] I. [Lisboa]: Imprensa Nacional-Casa da Moeda, 1996, p. 354-355.

${ }^{14}$ MARQUES, A. H. de Oliveira - "Para a História...", cit., p. 115.

${ }^{15}$ MORENO, Humberto Baquero - A Batalha ..., cit., vol. II, p. 759.

${ }^{16}$ Instituto Arquivos Nacionais/Torre do Tombo (Lisboa), Chancelaria de D. Afonso V, liv. 2, fl. 99; MORENO, Humberto Baquero - A Batalha ..., cit., vol. II, p. 759.

${ }^{17}$ Monumenta Henricina, vol. IX, p. 99-100; Documentação Henriquina. Maia: Castoliva Editora, 1995, p. 331, doc. 73.

${ }^{18}$ MORENO, Humberto Baquero - A Batalha ..., cit., vol. II, p. 760.

${ }^{19}$ Instituto Arquivos Nacionais/Torre do Tombo (Lisboa), Chancelaria de D. Afonso V, liv. 25, fl. 77; MORENO, Humberto Baquero - A Batalha ..., cit., vol. II, p. 760. 
todos os homens que com ele servissem ${ }^{20}$. Desconheciam-se, no entanto, quais os destinos específicos e alvos da missão. Porém, no dia seguinte, o mesmo D. Álvaro de Castro foi ordenado a formar uma armada para combater os corsários castelhanos que continuadamente andavam a roubar navios portugueses, castelhanos e outros que vinham comerciar ao Reino não respeitando o acordo de paz firmado entre Portugal e Castela. Nessa mesma carta requeria-se a ajuda das povoações portuárias portuguesas e castelhanas para que a armada de D. Álvaro de Castro pudesse rapidamente apanhar os ditos corsários:

"a todollos nossos naturaaes e sobdictos e jsso mesmo aos do dicto Rey de Castella que ssejam antes [sic] lhes emcomendamos que dem ao dicto dom Aluaro portos dos dictos Regnos e Senhorios [...] [e] toda a ajuda e fauor que poderem pera llogo os dictos cosairos serem pressos e filhados ssem dellonga"21.

Para além da ajuda no acesso a portos, sobretudo aos de Castela, seria sempre importante obter informações sobre o paradeiro dos corsários, talvez até o auxílio para a captura dos mesmos. De notar que a procura dos corsários estendia-se até águas castelhanas e havia uma legitimação para isso.

Não há informação de que o senhor de Cascais tenha tido êxito na sua missão. Contudo, posteriormente, continuou a comandar operações contra o corso, actividade em que esteve envolvido igualmente seu pai, D. Fernando de Castro $^{22}$, o qual também liderou uma expedição às Canárias sob ordens do infante D. Henrique (1424) ${ }^{23}$.

${ }^{20}$ VITERBO, Sousa - "Uma Expedição Portugueza às Canárias em 1440", in Archivo Historico Portuguez, 2. ${ }^{\text {a }}$ ed., vol. I, n. ${ }^{\circ}$ I. Lisboa: Imprensa Libanio da Silva, 1920, p. 348, doc. II; MARQUES, João Martins da Silva - Descobrimentos..., cit., sup. vol. I, p. 531, doc. 988.

${ }^{21}$ VITERBO, Sousa - "Uma Expedição...”, cit., p. 348, doc. III; MARQUES, João Martins da Silva - Descobrimentos..., cit., vol. I, p. 446-447, doc. 351.

${ }^{22}$ Pelo menos na área do Mediterrâneo, após a conquista de Ceuta (cf. CRUZ, Abel dos Santos - "A Guerra de Corso e a Pirataria no Mediterrâneo Ocidental ao tempo do Conde D. Pedro de Meneses (1415-1437)", in DOMINGUES, Francisco Contente e MATOS, Jorge Semedo de (org.), A Guerra Naval no Norte de África (séculos XV-XIX). Lisboa: Edições Culturais da Marinha, 2003, p. 80).

${ }^{23}$ AZURARA, Gomes Eanes de - Crónica do Descobrimento e Conquista da Guiné. Introd., actualização de texto e notas de Reis Brasil. [s.l.]: Publicações Europa-América, [s.d.], cap. LXXIX, p. 212-213; VITERBO, Sousa - Trabalhos Náuticos dos Portugueses. 
Como se pode imaginar, o processo de recrutamento para as armadas e a disponibilidade de navios eram problemáticos. Reunir os homens necessários e comandar uma armada não era tarefa fácil porque muitos se furtavam a isso, ou, por outro lado, porque poderiam surgir problemas com a falta de disciplina a bordo. Isto poderia complicar-se com a presença de criminosos nos navios já que estes habitualmente eram recrutados para as armadas. Na primeira carta dirigida a D. Álvaro de Castro é referido que todos os cavaleiros, fidalgos, escudeiros e todos os outros que fizessem parte da armada deveriam prestar obediência e fazer o que o senhor de Cascais ordenasse, caso contrário incorriam em "conprjmento de djreito e de justiça per todallas maneiras que per djreito achar ssalluo morte ou talhamento de nembros". Todavia, nos casos mais graves, aqueles que merecessem estas duas penas mais severas deveriam ser entregues à justiça por D. Álvaro de Castro, em qualquer lugar do Reino, sendo que a ordem era para que fossem enviados "aa nossa corte de conçelho em conçelho pera delles mandarmos fazer comprimento de djreito e justiça"24.

Enquanto camareiro-mor de D. Afonso V, e durante o período conturbado que precedeu a batalha de Alfarrobeira, D. Álvaro de Castro foi alvo de suspeição por parte dos inimigos do infante D. Pedro que o acusaram falsamente de dizer "amores aa Raynha", tentando que lhe fosse aplicada a pena de morte ou o desterro e que a rainha caísse na infâmia aos olhos do rei ${ }^{25}$. Rui de Pina refere mesmo que D. Álvaro de Castro chegou a ser preso, mas que o rei logo o "soltou e depois muito honrou e acrescentou"26. Não se sabe ao certo o tempo em que esteve preso e se participou ou não na batalha de Alfarrobeira (20 de Maio de 1449), sendo de admitir as duas hipóteses ${ }^{27}$. O certo é que, restabelecida a confiança do rei em D. Álvaro de Castro, por carta de 10 de Outubro de 1449 foi-lhe confirmada a posse da vila de Cascais e do reguengo de Oeiras ${ }^{28}$.

Séculos XVI e XVII. Introd. de José Manuel Garcia. Lisboa: Imprensa Nacional-Casa da Moeda, 1988, p. 252-253 [288-289].

${ }^{24}$ VITERBO, Sousa - "Uma Expedição...", cit., p. 348, doc. II.

${ }^{25}$ PINA, Rui de - "Chronica do Senhor Rey...”, cit., cap. CXIV, p. 736; MORENO, Humberto Baquero - A Batalha ..., cit., vol. II, p. 760.

${ }^{26}$ PINA, Rui de - "Chronica do Senhor Rey...", cit., cap. CXIV, p. 736.

${ }^{27}$ MORENO, Humberto Baquero - A Batalha ..., cit., vol. II, p. 761.

${ }^{28}$ MORENO, Humberto Baquero - A Batalha ..., cit., vol. II, p. 760. 
Em Dezembro de 1449 ocorreram conflitos entre cristãos e judeus lisboetas que culminam com o ataque e saque dos primeiros à judiaria grande de Lisboa e na morte de alguns judeus ${ }^{29}$. A este acontecimento "acudiram com muyta força" os oficiais de justiça e, principalmente, D. Álvaro de Castro, "que com suas forças atalharam ho mais roubo, e dano que se detriminava fazer" ${ }^{\prime 3}$. A 20 de Abril do ano seguinte foi confirmada a D. Álvaro de Castro a tença anual de 30.000 reais brancos, outorgados por casamento com D. Isabel, até perfazer a soma de 3.000 coroas $^{31}$. Esta confirmação de D. Afonso $\mathrm{V}$ surgiu em reconhecimento das muitas razões que o rei tinha para o fazer. Humberto Baquero Moreno supõe que uma das razões que levaram à confirmação dessa tença tenha a ver precisamente com a actuação de D. Álvaro de Castro na repressão ao saque da judiaria de Lisboa ${ }^{32}$.

Os serviços militares à Coroa iam sucedendo e o estatuto e riqueza de D. Álvaro de Castro iam aumentando. A 28 de Março de 1461, D. Álvaro de Castro foi nomeado fronteiro-mor da cidade de Lisboa e de seu termo. Para além de ficar na posse e encarregado da vigia do castelo, cabendo ao alcaide prestar-lhe obediência, D. Álvaro de Castro detinha a possibilidade de armar navios contra corsários, de requisitar as armas necessárias no armazém do rei e a "obrigação de evitar represálias de gentes do reino ou de fora dele" ${ }^{\prime 3}$. Logo em Novembro do mesmo ano, impelido pelos ventos, um barinel francês lançou ferro ao largo do Restelo. O mestre do navio, com receio de que os reconhecessem como franceses, inimigos de Portugal, facto que levaria a que o navio e a mercadoria fossem apresados, pediu ajuda a um navio da Biscaia que estava próximo para transferir a mercadoria para o seu interior enquanto os marinheiros franceses se espalharam por terra. A notícia chegou aos ouvidos de D. Álvaro de Castro, que, como fronteiro-mor de Lisboa, prontamente enviou à embarcação francesa um alcaide e

${ }^{29}$ Sobre este acontecimento, vide MORENO, Humberto Baquero - "O assalto à judiaria grande de Lisboa em Dezembro de 1449”, Marginalidade e Conflitos Sociais em Portugal nos Séculos XIV e XV. Estudos de História. Lisboa: Editorial Presença, 1985, p. 89-132.

${ }^{30}$ PINA, Rui de - "Chronica do Senhor Rey...", cit., cap. CXXX, p. 758-759.

${ }^{31}$ Instituto Arquivos Nacionais/Torre do Tombo (Lisboa), Chancelaria de D. Afonso V, liv. 34, fl. 62 .

${ }^{32}$ MORENO, Humberto Baquero - A Batalha ..., cit., vol. II, p. 761; MORENO, Humberto Baquero - "O assalto...," cit., p. 95-96 (n. 14).

${ }^{33}$ DUARTE, Luís Miguel - Justiça e Criminalidade..., cit., vol. II, p. 322-323. 
dois homens, um dos quais era Estêvão Anes, mestre de uma naveta de um mercador. Feita a confiscação da mercadoria, a maior parte dos produtos do barinel ficou na posse do conde de Monsanto, que ordenou a deslocação do navio para Lisboa. Parte da mercadoria que havia sido transferida para o navio biscainho acabou igualmente por ser tomada ${ }^{34}$.

Pelo ano de 1462, enquanto cavaleiro do conselho do rei, D. Álvaro de Castro recebia uma moradia mensal de 8.572 reais brancos ${ }^{35}$. No ano seguinte, em substituição de Galiote Pereira, que havia renunciado ao cargo de alcaide-mor do castelo de Lisboa, D. Álvaro de Castro foi empossado nesse cargo. Com a atribuição deste último cargo passou a usufruir de uma tença anual de 20.000 reais brancos ${ }^{36}$.

Já em 1468, D. Afonso V juntou à alcaidaria-mor de Lisboa, ocupada então por D. Álvaro de Castro, "as penas de sangue, semelhantes às da Corte, que ele decidira aplicar a quem matasse ou ferisse alguém na cidade ou seus arrabaldes, e que aquando da feitura da ordenação destinara à sua Câmara"37.

Um mês antes da tomada de Arzila, a 25 de Julho de 1471, D. Afonso V atribuiu uma tença anual de 28.571 reais brancos a D. Álvaro de Castro, para começar a usufruir a partir de 1 de Janeiro de 1472. Contudo, devido ao seu falecimento na tomada daquela praça africana, essa tença não teve efeito ${ }^{38}$.

Esta gradual acumulação de títulos e cargos que vemos em D. Álvaro de Castro foi típica entre as grandes famílias nobres do Reino nos séculos XIV e XV, nomeadamente no reinado de $\mathrm{D}$. Afonso $\mathrm{V}$. Na análise das famílias portuguesas mais importantes que acompanharam os monarcas em finais da Idade Média, Rita Costa Gomes notou que "a sucessão das gerações da mesma família no serviço régio" foi "acompanhada por um processo

${ }^{34}$ DUARTE, Luís Miguel - "Súbditos da Coroa de Aragão em Portugal no século XV - Comércio e segurança. Algumas notas", Revista da Faculdade de Letras. História. II, VII (1990) 78-80 e 82-83, doc. 3.

${ }^{35}$ MORENO, Humberto Baquero - A Batalha ..., cit., vol. II, p. 763.

${ }^{36}$ Foi igualmente investido como couteiro-mor das perdizes de Lisboa e seu termo, cargo obtido também em substituição de Galiote Pereira (MORENO, Humberto Baquero A Batalha ..., cit., vol. II, p. 762).

${ }^{37}$ DUARTE, Luís Miguel - Justiça e Criminalidade..., cit., vol. II, p. 330.

${ }^{38}$ MORENO, Humberto Baquero - A Batalha ..., cit., vol. II, p. 763. 
de alargamento e de diversificação no âmbito da actuação e nas funções desempenhadas pela nobreza" ${ }^{39}$. Os Castro não foram excepção.

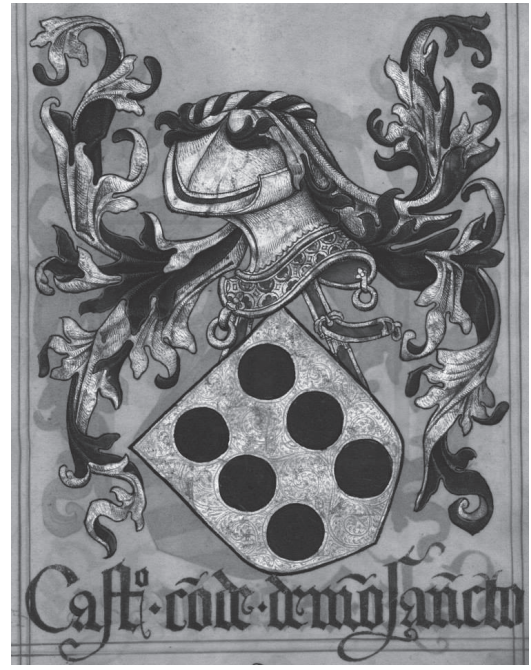

Fig. 1 - Brasão de armas dos Castro, condes de Monsanto (Instituto Arquivos Nacionais/Torre do Tombo (Lisboa), Livro do Armeiro-mor, fl. 49).

\section{D. Álvaro de Castro nas expedições militares a Marrocos}

Com o desenrolar das expedições militares a Marrocos e a manutenção dos locais conquistados, aumentou o movimento nos portos do Reino onde se aprestavam os navios com mantimentos. Para Ceuta, Tânger, Alcácer Ceguer, Arzila e outras praças de guerra africanas partiram numerosas expedições que movimentaram toneladas de alimentos, materiais e milhares de homens de diferentes condições sociais e realidades geográficas. D. Álvaro de Castro foi um entre os muitos nobres que comandaram grupos militares em solo marroquino com gentes de diferentes origens geográficas. O facto de senhorear várias terras elevava as possibilidades de prestar auxílio armado ao rei, quando este decidisse levar a cabo uma expedição militar, e de comandar as forças dos seus senhorios em qualquer parte.

${ }^{39}$ GOMES, Rita Costa - A Corte dos Reis de Portugal no final da Idade Média. Lisboa: Difel, 1995, p. 87. 


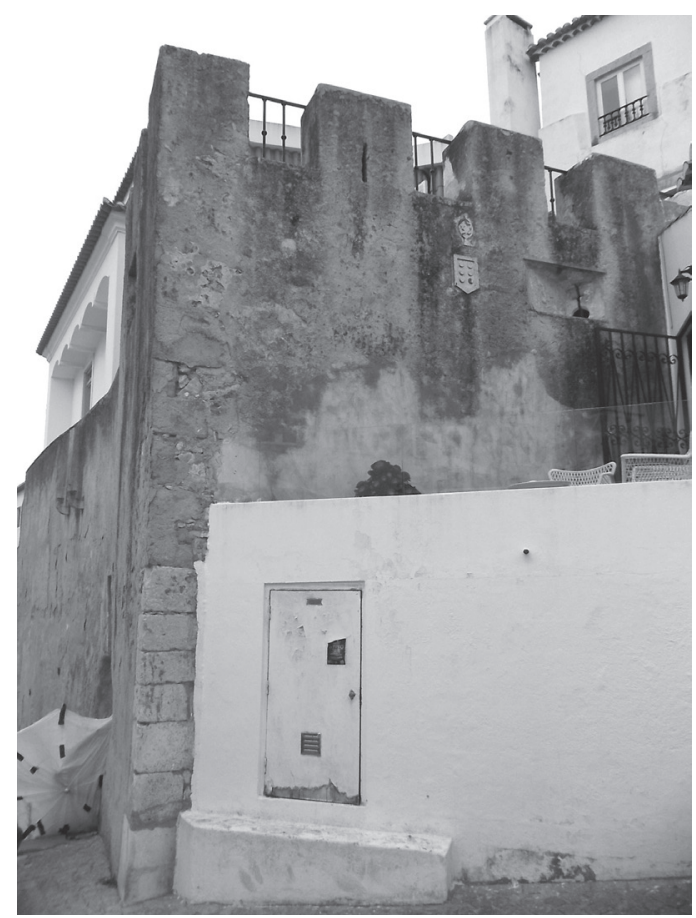

Fig. 2 - Torre-porta da muralha medieval (geralmente chamada castelo) de Cascais. Ao centro, o brasão dos Castro sobreposto por uma esfera armilar, à direita, uma troneira.

No caso cascalense, aquele que conhecemos melhor, sabe-se que a ligação às campanhas militares vem desde as origens do poder senhorial nesta vila. Em 1370 foi fundado o senhorio de Cascais, sendo entregue, juntamente com o castelo da vila, a Gomes Lourenço do Avelar. Esta doação, feita de forma hereditária, surgiu em consideração dos serviços prestados por este poderoso valido do rei e heróico defensor de Ciudad Rodrigo na luta que no ano anterior havia estalado contra Castela. Daí em diante, e sempre que necessário, Gomes Lourenço do Avelar e os seus sucessores continuariam a assegurar o auxílio militar à Coroa com determinado número de lanças e a proceder à defesa do seu senhorio ${ }^{40}$. Porém, com o início da expansão marítima do século XV, é em Marrocos que os senhores de Cascais se vão destacar e garantir esse auxílio armado, fazendo-se acompanhar dos seus combatentes e de outros recrutados para a ocasião - expedicionários de baixa

${ }^{40}$ MARQUES, A. H. de Oliveira - "Para a História...”, cit., p. 130. 
condição social que arriscaram a vida numa terra mal conhecida e que as crónicas não registaram ${ }^{41}$.

A expedição que rumou a Tânger largou do Restelo a 22 de Agosto de 1437 sob comando do infante D. Henrique, na altura com 43 anos de idade. Durante o embarque D. Henrique recebeu três documentos de recomendação, entre os quais um regimento ordenado por D. Duarte e uma carta de D. Pedro. O rei havia delineado que, uma vez chegada a Ceuta (27 de Agosto), a frota deveria ser dividida em três frentes, cada uma a surgir de surpresa frente a Tânger, Alcácer e Arzila, mas a verdade é que D. Henrique não respeitou tais ordens ${ }^{42}$. Inversamente ao previsto, D. Henrique enviou uma coluna de mil homens para explorarem o caminho mais curto entre Ceuta e Tânger, mas os ataques mouros levaram o comandante a optar pelo caminho mais longo, ou seja, por Tetuão ${ }^{43}$.

Nesta expedição não terá participado D. Afonso de Cascais ${ }^{44}$, senhor daquela vila, o qual havia comandado as forças cascalenses em Ceuta (1415 e 1418-1419) ${ }^{45}$. Todavia, entre os capitães, fidalgos e pessoas principais da casa do infante D. Henrique que seguiram na dura caminhada até Tânger, estava D. Fernando de Castro $^{46}$, governador de sua casa e alcaide-mor da Covilhã, acompanhado por dois dos seus filhos: D. Álvaro de Castro, futuro

${ }^{41}$ Sobre a presença dos nobres nas expedições militares ao Norte de África, vide CRUZ, Abel dos Santos - A Nobreza Portuguesa em Marrocos no Século XV (1415-1464). Dissertação de Mestrado em História Medieval (FLUP): 1995.

${ }^{42}$ COELHO, António Borges - "Henrique, o navegador", Questionar a História II. Clérigos, Mercadores, «Judeus» e Fidalgos. Lisboa: Editorial Caminho, 1994, p. 71.

${ }^{43}$ Para António Dias Farinha, ao seguir aquela caminhada, o infante D. Henrique tinha como plano tomar o domínio das terras vizinhas, "ocupar o território norte de Marrocos, submeter os seus habitantes, estabelecer laços vassálicos e conseguir parceiros comerciais" (FARINHA, António Dias - Portugal e Marrocos no Século XV. Dissertação de Doutoramento em História (FLUL), vol. I: 1990, p. 145).

${ }^{44}$ Rui de Pina não indica o nome deste nobre entre os combatentes que estiveram em Tânger.

${ }^{45}$ ZURARA, Gomes Eanes de - Crónica da Tomada de Ceuta. Pref. e actualização de textos de Carlos Miranda. Lisboa: Editorial Escol, [s.d.], cap. L, p. 109-110; AZEVEDO, Pedro de - Documentos das Chancelarias Reais anteriores a 1531 relativos a Marrocos, t. I. Coimbra: Imprensa da Universidade, 1915, p. 506-507; BORGES, Marco Oliveira O Porto de Cascais..., cit., p. 131-132 e 139-141.

${ }^{46} \mathrm{Tal}$ como o infante D. Henrique, D. Fernando de Castro surge associado às pessoas que tiveram cargo nas despesas com a frota de Tânger (MARQUES, João Martins da Silva - Descobrimentos..., cit., sup. vol. I, p. 515, doc. 919). 
senhor de Cascais, e D. Henrique de Castro ${ }^{47}$. Estes fidalgos, ocupando-se da ala direita juntamente com a sua gente de armas, partiram logo após a saída da vanguarda sob comando do conde de Arraiolos ${ }^{48}$.

$\mathrm{Na}$ ausência de D. Afonso de Cascais, teria D. Álvaro de Castro comandado as forças militares de Cascais em Tânger? É possível que sim. Não se conhece o motivo da ausência de D. Afonso de Cascais - também alcaide-mor de Lisboa - naquela expedição. Talvez isso tenha acontecido pela sua idade avançada (c. 67 anos), por doença ou por um impedimento de outra ordem que o tenha levado a ficar em Portugal ${ }^{49}$. Assim sendo, é possível que D. Álvaro de Castro, futuro senhor de Cascais, tenha substituído o sogro e comandado as forças cascalenses ${ }^{50}$.

Quanto à expedição, desde a falta de homens ao material incapaz, à artilharia que não operou como se esperava até às dificuldades sentidas no terreno, esta revelou-se mal orientada resultando num fracasso absoluto e que seria agravado com o cativeiro do infante D. Fernando, vindo a atrasar a "realização marroquina" 51 .

Apenas três anos depois, em Abril de $1440^{52}$, D. Álvaro de Castro participou numa expedição a Ceuta com o objectivo de resgatar o infante D. Fernando, na altura cativo em Fez, em troca da cidade ceptense. A expedição seria comandada por D. Fernando de Castro, seu pai. Contudo, durante a viagem o navio de D. Fernando de Castro foi surpreendido por uma carraca de corsários genoveses, já perto do cabo de S. Vicente, travando-se um combate que resultou na morte do próprio D. Fernando de Castro $^{53}$.

${ }^{47}$ PINA, Rui de-Crónica do Rei..., cit., cap. XV, p. 100; MORENO, Humberto Baquero - A Batalha ..., cit., vol. II, p. 758-759.

${ }^{48}$ PINA, Rui de - Crónica do Rei..., cit., cap. XXIII, p. 136.

${ }^{49}$ BORGES, Marco Oliveira - O Porto de Cascais..., cit., p. 132.

${ }^{50}$ Sabemos que D. Álvaro de Castro comandou uma companha nesta expedição. A 13 de Abril de 1446 foi concedida a Diogo Pires a isenção de servir como besteiro do conto por ter servido na companha de D. Álvaro de Castro, em Tânger, com cavalos e armas (AZEVEDO, Pedro de - Documentos..., cit., t. I, p. 314).

${ }^{51}$ A expressão é de GODINHO, Vitorino Magalhães - Portugal. A Emergência de uma Nação (das raizes a 1480). Lisboa: Edições Colibri, 2004, p. 102.

${ }^{52}$ Embora, erradamente, Rui de Pina e Frei João Álvares indiquem Abril de 1441 (cfr. Monumenta Henricina, vol. VII, p. 176-177 (n. 1); MORENO, Humberto Baquero A Batalha ..., cit., vol. II, p. 759 (n. 3) e 984 (n. 2)).

${ }^{53} \mathrm{O}$ corsário haveria de ser identificado como sendo Bartolomeu Serrato, cidadão de Savona, sendo obrigado a reembolsar em dinheiro D. Álvaro de Castro pela presa que os 
Já em Ceuta, D. Álvaro de Castro escreveu ao infante Regente a contar o triste sucedido, "pedindo-lhe ordenança e provysam pera o futuro" ${ }_{54}$. A "capitania e negócio" da expedição acabaria por ser confiada a D. Álvaro de Castro, que não foi coroado de êxito, já que os mouros exigiram em primeiro lugar a entrega de Ceuta e só depois a libertação de D. Fernando. Bloqueada a missão, D. Pedro ordenou que D. Álvaro de Castro regressasse ao Reino para se discutir outra forma que permitisse a libertação de D. Fernando ${ }^{55}$.

Referindo-se a uma expedição à costa ocidental africana ocorrida em 1445, Gomes Eanes de Zurara menciona que Dinis Dias (descobridor do cabo Verde) armou uma caravela de D. Álvaro de Castro e que, juntamente com Álvaro Fernandes Palenço, piloto de uma fusta velha, pretendia chegar à "terra dos negros". A primeira paragem foi na ilha de Arguim, local onde fizeram aguada. Após passarem a ponta de Santa Ana doze dos tripulantes saltaram em terra vindo a capturar nove indígenas, três dos quais acabaram por conseguir fugir ${ }^{56}$. Embora Zurara não refira a sua presença, somente que "Dinis Dias armou uma caravela de Dom Álvaro de Castro, tomando logo de começo companhia com Palenço" ${ }^{57}$, Ferreira de Andrade ${ }^{58}$ e João Silva de Sousa $^{59}$ afirmaram que D. Álvaro terá participado nesta mesma expedição. Dado os ofícios que desempenhava e as responsabilidades acrescidas referentes a isso, e que deveriam ocupar-lhe bastante tempo, não é de crer

genoveses tomaram a seu pai dez anos antes (Monumenta Henricina, vol. VII, p. 176-177 (n. 1), vol. X, p. 163-164, doc. 103, p. 169-170, doc. 111, p. 178-179, doc. 119). Desconhece-se, no entanto, se chegou a efectuar o pagamento.

${ }^{54}$ PINA, Rui de - "Chronica do Senhor Rey...", cit., cap. LIV, p. 653.

${ }^{55}$ PINA, Rui de - "Chronica do Senhor Rey...", cit., cap. LIV, p. 650-653; ÁLVARES, Fr. João - Chronica do Infante Santo D. Fernando. Coimbra: F. França Amado - Editor, 1911, cap. XXV, p. 68-73; MORENO, Humberto Baquero - A Batalha ..., cit., vol. II, p. 759 (n. 3) e 984 (n. 2); CRUZ, Abel dos Santos - A Nobreza Portuguesa ..., cit., p. 132 (n. 14); COSTA, João Paulo Oliveira e - Henrique, o Infante. Lisboa: A Esfera dos Livros, 2009, p. 261-262.

${ }^{56}$ AZURARA, Gomes Eanes de - Crónica do Descobrimento..., cit., cap. XXXI, p. 110, cap. LXXI, p. 192-195.

${ }^{57}$ AZURARA, Gomes Eanes de-Crónica do Descobrimento ..., cit., cap. LXXI, p. 192.

${ }^{58}$ ANDRADE, Ferreira de - Cascais..., cit., p. 74 (n. 27).

${ }^{59}$ SOUSA, João Silva de - A Casa Senhorial do Infante D. Henrique. Lisboa: Livros Horizonte, 1991, p. 399. 
que tenha seguido viagem. Aliás, nem era esse o seu tipo de envolvimento pessoal na empresa africana, como teremos oportunidade de ver adiante ${ }^{60}$.

Já se viu que o senhor de Cascais participou na expedição desastrosa a Tânger, onde comandou um grupo militar, e que, em Abril de 1440, tomou parte da expedição mal sucedida que rumou a Ceuta com o objectivo de entregar esta cidade em troca do resgate do infante D. Fernando. Embora não tenha participado na tomada de Ceuta, uma vez que deveria ser muito novo ou nem sequer havia nascido, são várias as cartas, especialmente de perdão, de indulto e de comutação de penas a escudeiros e a degredados sob seu comando, que nos dão conta das suas movimentações para aquela praça. De facto, entre 1442 e 1456 surgem vários documentos que nos indicam - de forma directa ou indirecta - a presença de D. Álvaro de Castro em Ceuta com bastante frequência.

Uma carta de 8 de Maio de 1442 revela que Diogo Gonçalves de Aguiar, escudeiro de D. Álvaro de Castro, enquanto moço de treze anos, havia esfaqueado um lavrador após este ter desferido uma bofetada no seu pai. Esta carta remete para outra outorgada por D. Duarte em que o monarca havia perdoado tal acto a Diogo Gonçalves de Aguiar mediante o serviço de um ano e meio em Ceuta. Com efeito, Diogo Gonçalves de Aguiar acabou por servir durante esse período na companha de D. Álvaro de Castro, comprovando esse serviço ao rei mediante um alvará do senhor de Cascais. Porém, como o serviço fora feito num espaço de tempo posterior ao que D. Duarte havia delimitado, o escudeiro temia ter incorrido em pena, daí que solicitasse que lhe fosse concedido o perdão. O perdão acabaria por ser concedido, contanto que Diogo Gonçalves de Aguiar fosse servir por quatro meses seguidos ao couto de Arronches, sendo que daí em diante teria liberdade para viver em qualquer lugar do Reino ${ }^{61}$.

${ }^{60}$ De qualquer forma, fica por saber se D. Álvaro de Castro colocou excepcionalmente uma caravela sua à disposição dos navegadores do infante $\mathrm{D}$. Henrique, mediante frete, ou, por outro lado, se o envolvimento dos seus navios poderia ter outro tipo de frequência nas viagens de exploração pela costa ocidental africana. O mais provável é que a caravela apenas tenha sido fretada a D. Álvaro, não havendo qualquer ligação habitual com as viagens de exploração henriquinas.

${ }^{61}$ Instituto Arquivos Nacionais/Torre do Tombo (Lisboa), Chancelaria de D. Afonso V, liv. 35, fl. 101v; AZEVEDO, Pedro de-Documentos ..., cit., t. II, p. 660-661. 
Esta carta não permite situar a data em que se desenrolou esse serviço militar de um ano e meio em Ceuta, na companha de D. Álvaro de Castro. Aliás, os documentos que revelam as ligações de D. Álvaro de Castro ao serviço militar em Ceuta apenas mostram as penas aplicadas e cumpridas pelos homiziados e degredados e nunca as datas exactas das viagens e serviços prestados. Todavia, a dita carta permite perceber que, pelo menos desde 1441, D. Álvaro de Castro comandava forças militares em solo ceptense.

Também não sabemos quais as épocas e as escalas destas viagens. Todavia, um documento de 1 de Abril de 1455 revela que, na vinda de Ceuta, as forças militares de D. Álvaro de Castro escalaram em Faro ${ }^{62}$. O documento remete para cerca de três meses antes, pouco mais ou menos, pelo que a chegada teria ocorrido algures entre Janeiro e Fevereiro. Não se sabe igualmente o motivo que levou à passagem das forças militares por Faro e se esta era, ou não, uma escala frequente no retorno de Ceuta. Todavia, o facto de que, por esta altura, D. Álvaro de Castro já tinha um criado fixo naquela vila algarvia, o qual haveria de ficar ligado às salinas locais, leva-nos a suspeitar de algo mais ${ }^{63}$.

A 28 de Maio de 1446 foi emitida uma carta na qual é referido que Pedro de Lisboa, escudeiro de D. Álvaro de Castro, havia feito queixa de que a sua irmã, casada com Afonso Gonçalves do Soveral (colaço de D. Duarte), e enquanto grávida, havia sido atacada por Afonso Anes da Pederneira. Ao disparar uma besta, Afonso Anes acertou-lhe num olho tirando a sua vida e a da criança de sete meses que trazia no ventre. Consequentemente, o criminoso refugiou-se no couto do mosteiro de Alcobaça. Sem respeito à justiça, vinha de vez em quando à cidade de Lisboa onde o irmão da vítima o ameaçava com o mesmo tratamento, até que um dia o feriu mortalmente pela espada. Por esta razão, Pedro de Lisboa saiu para Castela e mais tarde teve de seguir com D. Álvaro de Castro para Ceuta onde serviu dois anos. No retorno ao Reino o escudeiro incorporou uma expedição a Castela - certamente Olmedo - sob comando do condestável. Posteriormente,

${ }^{62}$ AZEVEDO, Pedro de - Documentos ..., cit., t. II, p. 263-264.

${ }^{63} \mathrm{O}$ criado era Álvaro Afonso, o qual, a pedido do próprio D. Álvaro de Castro, foi nomeado para o ofício de medidor do sal das salinas e casa do sal da dita vila. A carta é de 14 de Fevereiro de 1455 (Instituto Arquivos Nacionais/Torre do Tombo (Lisboa), Chancelaria de D. Afonso $V$, liv. 15, fl. $7 \mathrm{v})$. 
veio a solicitar que a pena que lhe fora aplicada fosse perdoada, facto que ficou estipulado mediante outro serviço "aa nossa cidade de Cepta per sseu corpo sseis anos conpridos" $"$.

Por uma carta de quitação de 2 de Março de 1456, relativa às despesas feitas entre 1453-1454 pelo tesoureiro-mor das coisas de Ceuta em Lisboa, é referido que D. Álvaro de Castro, para além de vários alimentos, recebeu 13.150 reais de soldo e mantimento de dois meses para servir naquela praça com cinquenta escudeiros, besteiros e quinze homens de pé ${ }^{65}$.

Para Ceuta também partiam algumas mulheres. Logo após ser tomada a decisão de que se deveria conservar aquela praça de guerra permanentemente, algumas mulheres portuguesas foram enviadas para Ceuta com os seus companheiros, situação que também aconteceu noutras fortalezas costeiras à medida que os portugueses se iam estabelecendo no Norte de África ${ }^{66}$. Assim, por exemplo, numa carta de 24 de Março de 1453 é referido que Leonor de Beja, natural de Lisboa e manceba de Gil Gusmão, escudeiro de D. Álvaro de Castro, havia partido com ambos para Ceuta. Não se sabe a data em que partiram, mas presume-se ter sido pelo ano de 1452. Posteriormente, já no Reino, Leonor de Beja haveria de ser açoutada e condenada ao degredo "pera senpre" ${ }^{67}$. D. Afonso V, no entanto, acabaria por lhe conceder o perdão, sendo que o mesmo só seria válido consoante outras contrapartidas da parte da manceba.

Por carta de 29 de Setembro de 1456 é referido que João Lourenço, morador na Castanheira, "querellara" de Henrique da Costa, escudeiro de D. Álvaro de Castro, por este ter levado sua mulher, Briolanja Rodrigues, e outras coisas de sua casa "pequando lhe com ella na ley do casamento". Por esta razão Henrique da Costa andava homiziado "con temor das nosas justiças", acabando por se oferecer para servir na cidade de Ceuta depois de Janeiro de 1456. Ao oferecer-se para servir em Ceuta, Henrique da Costa esperava, posteriormente, conseguir ser perdoado da dita querela mediante o perdão geral concedido aos que foram na armada contra o turco. O caso

${ }^{64}$ AZEVEDO, Pedro de-Documentos..., cit., t. I, p. 321-322.

${ }^{65}$ Vide infra, n. 123.

${ }^{66}$ C. R. Boxer - A Mulher na Expansão Ultramarina Ibérica 1415-1815. Alguns factos, ideias e personalidades. Trad. de Saúl Barata. Lisboa: Livros Horizonte, 1977, p. [13].

${ }^{67}$ AZEVEDO, Pedro de - Documentos ..., cit., t. II, p. 155-156. 
prolongou-se por algum tempo, vindo Henrique da Costa a solicitar a D. Álvaro de Castro que interviesse a seu favor perante o rei. Posto isto, ficou determinado que Henrique da Costa teria de servir por três anos em Ceuta, sendo que os dois primeiros seriam à sua custa e o postumeiro à do rei ${ }^{68}$.

Não obstante as várias indicações surgidas na documentação revelarem que seria corrente a presença de D. Álvaro de Castro em Ceuta, aonde chegou a estar ano e meio sem interrupção $0^{69}$, não nos surge nenhuma indicação de gentes de Cascais a servir nessa praça durante esse período. Contudo, tal não significa que assim tenha sido visto que o mesmo D. Álvaro tinha escudeiros oriundos daquela vila e termo ao seu serviço.

Durante o período em que D. Álvaro de Castro senhoreou Cascais, mais precisamente por carta de 20 de Novembro de 1445, D. Afonso V nomeou Álvaro Afonso, escudeiro do próprio D. Álvaro e morador em Cascais, para o cargo de coudel da dita vila durante cinco anos. Álvaro Afonso substituía assim Fernão Vasques, que havia terminado o seu tempo de exercício do cargo durante cinco anos, período que se infere pelas indicações da carta, tal como os anteriores coudéis ${ }^{70}$. Desta feita, o escolhido seria, aliás, um homem da confiança do senhor de Cascais, o que lhe garantiria certamente uma melhor gestão dos recursos humanos disponíveis para a guerra. Note-se que "os nobres a quem eram doadas terras, rendas e outros bens para servirem o monarca com um determinado número de lanças tratavam de assegurar o recrutamento destas nos seus próprios senhorios, nas terras sobre as quais tinham jurisdição ou influência, junto dos seus próprios vassalos e dependentes" "ᄁ1. Todavia, as populações também chegavam a enfrentar arrolamentos ilegais levados a cabo pelos

${ }^{68}$ AZEVEDO, Pedro de - Documentos..., cit., t. II, p. 585.

${ }^{69}$ Carta de 8 de Maio de 1442. Vide supra, n. 61.

${ }^{70}$ Instituto Arquivos Nacionais/Torre do Tombo (Lisboa), Chancelaria de D. Afonso V, liv. 5, fl. 3v. Os coudéis eram oficiais de nomeação régia que teoricamente exerciam a sua função entre 3 a 5 anos, embora por vezes se eternizassem nos seus cargos o que facilitava o tráfico de influências e muitos abusos, sendo que o momento propício para tal era na altura dos alardos, ou seja, "das revistas ou mostras" (MONTEIRO, João Gouveia - "Organização e formação militares", in BARATA, Manuel Themudo e TEIXEIRA, Nuno Severiano (dir.), Nova História Militar de Portugal, vol. I. Lisboa: Círculo de Leitores, 2003, p. 197).

${ }^{71}$ MONTEIRO, João Gouveia - "Organização e formação...”, cit., p. 193. 
fidalgos que não obedeciam ao apuramento seguido pelos coudéis ${ }^{72}$, sendo que muitos acabariam por ser recrutados sem ter qualquer experiência no manejo de armas $^{73}$.

Sabe-se que era, sobretudo, com condenados, prisioneiros e degredados que se aumentava a população ceptense, tal como acontecia em "tantas zonas inóspitas continentais" e nas ilhas Atlânticas ${ }^{74}$. Os crimes mais comuns que davam direito ao degredo diziam respeito à fabricação de moeda falsa, traição, morte, adultério, homossexualidade e roubo. Para os criminosos acusados de sodomia a pena capital seria a morte pelo fogo ${ }^{75}$. Todavia, ocorriam casos em que o monarca perdoava como gesto de compensação aos que tinham servido ou fossem servir na guerra sob condição de degredados. Foi o caso de João da Mata, um dos criados do conde de Monsanto que, juntamente com outros indivíduos mouros, foi acusado de que "com certos delles obrava de sodomia e a outros alcouveitava chistãaos com que dormia" na cidade de Lisboa. Todavia, por carta de 4 de Fevereiro de 1464, beneficiou do perdão geral concedido aos homiziados presentes na armada real que rumou a Ceuta $^{76}$.

A 25 de Novembro de 1471, no seguimento do perdão geral concedido aos homiziados que tinham servido na tomada de Arzila $^{77}$, e reconhecendo

${ }^{72}$ BARROS, Amândio - "A Preparação das Armadas no Portugal de Finais da Idade Média”, Revista da Faculdade de Letras. História, II, VII (1990) 125.

${ }^{73}$ Reportando-se desde logo ao recrutamento das gentes da Beira que D. Henrique fez para a tomada de Ceuta, Zurara dizia: "uma coisa é lidar com porcos monteses na Beira, outra é pelejar com homens armados que se sabem defender" (ZURARA, Gomes Eanes de - Crónica da Tomada..., cit., cap. XLIX, p. 109).

${ }^{74}$ SOUSA, João Silva de - A Casa Senhorial..., cit., p. 120. Se o degredado abandonasse o local antes do cumprimento da pena era condenado ao dobro do tempo que lhe restava. Caso a sua pena fosse de dez anos ou mais e fosse interrompida antes do tempo estabelecido pela justiça, o degredado seria condenado a pena perpétua sendo que, caso quebrasse o degredo perpétuo, seria condenado à morte (Ordenações Afonsinas, liv. V, tít. LXVII. Lisboa: Fundação Calouste Gulbenkian, 1984, p. 272-274).

75 "Seja queimado, e feito per fogo em poo" (cf. Ordenações Afonsinas, liv. V, tít. XVII, p. 54).

${ }^{76}$ Pub. por FARINHA, António Dias - Portugal e Marrocos..., cit., vol. II, p. 278.

${ }^{77}$ Sobre os criminosos que serviram na tomada de Arzila, vide DUARTE, Luís Miguel e PIZARRO, José Augusto P. de Sotto Mayor - "Os forçados das galés (os barcos de João da Silva e Gonçalo Falcão na conquista de Arzila em 1471", in Congresso Internacional Bartolomeu Dias e a sua Época. Actas, vol. II - Navegações na segunda metade do século XV. Porto: Universidade do Porto, Comissão Nacional para as Comemorações dos Descobrimentos Portugueses, 1989, p. 313-328. 
os instrumentos públicos feitos a seu favor pelos familiares de Vasco Anes (mancebo de soldada dos frades da Penha Longa), João Domingues teve a sua pena perdoada. O carpinteiro, habitante no termo da vila de Cascais, havia sido acusado do homicídio do amante de sua esposa, ou seja, Vasco Anes, o qual "dormia carnallmemte e lhe pecaua na ley do casamemto com ssua molher"78. Este cascalense teria feito parte do contingente militar que o conde de Monsanto chefiou durante a tomada de Arzila ${ }^{79}$.

Recuemos uns anos. Em relação à expedição que rumou a Alcácer Ceguer em 1458, na qual também participou D. Álvaro de Castro, sabe-se que partiu do porto de Setúbal a 30 de Setembro. Embora Tânger fosse o principal objectivo militar português, quer pelo valor estratégico, quer pela carga simbólica que tal conquista assumia, o monarca optou pela vila de Alcácer Ceguer. De Setúbal a frota seguiu para Sagres, onde já os esperava a frota comandada pelo infante D. Henrique, e daí rumaram a Lagos, ponto de encontro com a frota do Marquês de Valença vinda do Porto. Rui de Pina indica que a partida final seria a 17 de Outubro, sendo que a frota que largou de Lagos era composta por 220 velas $^{80}$, enquanto que Damião de Góis refere "vinte e seis mil homens de peleja, e duzentas e oitenta naus, galés, e outros navios de carga, e serviço"

Como habitualmente, em mais uma campanha marroquina terá estado presente o contingente militar de Cascais sob comando do seu senhor, D. Álvaro de Castro. Não é possível determinar o número de homens de Cascais envolvidos nesta campanha, nem, aliás, nas outras. Rui de Pina apenas revela que D. Álvaro de Castro esteve presente na conquista de Alcácer Ceguer junto do monarca ${ }^{82}$, tendo partido inclusive do porto de

${ }^{78}$ Instituto Arquivos Nacionais/Torre do Tombo (Lisboa), Chancelaria de D. Afonso V, liv. 17 , fl. 86.

${ }^{79}$ Ainda em 1471, por carta de 14 de Março, o rei perdoou Pedro Fernandes, escudeiro do conde de Monsanto, por ajudar no trato clandestino de cereais com Castela e estar associado a alguns castelhanos (DUARTE, Luís Miguel -"O comércio proibido", in Estudos em Homenagem a João Francisco Marques, vol. I. Porto: Faculdade de Letras da Universidade do Porto, 2001, p. 415).

${ }^{80}$ PINA, Rui de - "Chronica do Senhor Rey...", cit., cap. CXXXVIII, p. 776.

${ }^{81}$ GÓIS, Damião de - Crónica do Príncipe..., cit., cap. X, p. 32.

${ }^{82}$ PINA, Rui de - "Chronica do Senhor Rey...", cit., cap. CXXXVIII, p. 463. 
Setúbal no mesmo navio que o rei, a nau Santo António, em conjunto com mais de noventa velas ${ }^{83}$.

Após a tomada de Alcácer Ceguer o monarca criou a Ordem da Espada (1458-1459), destinada a premiar os nobres pelos serviços prestados nas campanhas do Norte de África. Limitada a 27 pessoas, o senhor de Cascais terá tido a honra de ser um dos primeiros iniciados nesta Ordem ${ }^{84}$. Pela prestação exemplar nas campanhas marroquinas e grandes serviços prestados à coroa, $\mathrm{D}$. Afonso $\mathrm{V}$ concedeu-lhe o título de conde de Monsanto a 21 de Maio de 1460. Da doação constava aquela vila e castelo com seu termo, jurisdição cível e crime, padroado de igrejas, sisas gerais, sisas dos vinhos e panos, ressalvando a correição e alçada para o rei ${ }^{85}$. Posteriormente, por carta de 20 de Maio de 1464, a doação desta vila e castelo passou a ser de juro e herdade para sempre ${ }^{86}$ até que, por carta 8 de Dezembro de 1469 , o senhorio passou a ser transmitido aos herdeiros varões sem necessidade de outro diploma ${ }^{87}$.

Entre Novembro de 1463 e a Páscoa de 1464, D. Afonso V esteve entre Ceuta e Alcácer Ceguer onde desenvolveu três tentativas mal sucedidas de conquistar Tânger e outra de Arzila. A 19 de Janeiro de 1464, numa das investidas a Tânger levadas a cabo pelo infante D. Fernando, irmão do rei, D. Álvaro de Castro veio a perder um dos seus filhos, D. Jorge de Castro, quando este apoiava o infante ${ }^{88}$. Posteriormente, D. Álvaro de Castro partiu de Ceuta com D. Afonso V rumo a Gibraltar. Ali mesmo, por influência do conde de Ledesma e a pedido do próprio rei de Castela, o monarca

${ }^{83}$ PINA, Rui de - "Chronica do Senhor Rey...", cit., cap. CXXXVIII, p. 775.

${ }^{84}$ Porém, esta Ordem viria a desaparecer em 1481 com a morte de D. Afonso V (cf. MARQUES, A. H. de Oliveira - "Os Grupos Sociais", in SERRÃO, Joel e MARQUES, A. H. de Oliveira (dir.), Nova História de Portugal, vol. IV - Portugal na Crise dos séculos $X I V$ e $X V$. Lisboa: Editorial Presença, 1986, p. 261; MARQUES, A. H. de Oliveira - "Para a História...", cit., p. 128).

${ }^{85}$ FREIRE, Anselmo Braamcamp - Brasões ..., cit., 2. ${ }^{\text {a }}$ ed., liv. seg. Coimbra: Imprensa da Universidade, 1927, p. 88; Humberto Baquero - A Batalha ..., cit., vol. II, p. 761.

${ }^{86}$ Instituto Arquivos Nacionais/Torre do Tombo (Lisboa), Chancelaria de D. Afonso V, liv. 8, fl. 67-67v; FREIRE, Anselmo Braamcamp - Brasões..., cit., p. 88; Humberto Baquero - A Batalha ..., cit., vol. II, p. 761-762.

${ }^{87}$ FREIRE, Anselmo Braamcamp - Brasões..., cit., p. 88; Humberto Baquero A Batalha..., cit., vol. II, p. 761-762.

${ }^{88}$ PINA, Rui de - "Chronica do Senhor Rey...", cit., cap. CLIII, p. 808. 
português encontrou-se com o seu homólogo, Henrique IV $^{89}$. Durante oito dias esboçou-se "uma perspectiva de colaboração futura entre os reinos" devido aos problemas de sucessão relativos ao trono de Castela que tinham surgido com a revolta dos nobres castelhanos, isto após "Henrique IV, cedendo às pressões da rainha e de D. Beltran, ter declarado a pequena Joana como sucessora legítima" $"$.

Decidido a não partir para o Reino sem nenhum feito de destaque, D. Afonso V, logo nos primeiros dias de Fevereiro de $1464^{91}$, investiu sobre a serra de Benacofú, local onde existiam mouros "ferozes em armas"92. Contudo, as condições do terreno dificultaram as operações dos portugueses, nomeadamente dos cavaleiros, com os mouros a reprimirem as forças portuguesas através da encosta ${ }^{93}$, causando muitos mortos ao ponto de colocar em risco a vida do próprio rei. Esta atitude imprudente do monarca, que se aventurava por uma serra que não conhecia e que, para além disso, havia deslocado para Tetuão alguma gente de armas que o acompanhava (besteiros, espingardeiros e peões) ${ }^{94}$, obrigou a que D. Duarte de Meneses, capitão de Alcácer Ceguer, cobrisse a sua fuga, vindo este a sacrificar a sua vida enquanto garantia a segurança real.

Quem também não deixou de estar em perigo durante a fuga foi D. Álvaro de Castro, um dos principais capitães presentes na aventura a Benacofú ${ }^{95}$, e que tentou o salvamento de D. Duarte de Meneses, seu cunhado. Zurara diz que tendo os mouros morto o cavalo de D. Duarte e ferido este "na traseyra", chegou a ele D. Álvaro de Castro com um escudeiro chamado

${ }^{89}$ PINA, Rui de - "Chronica do Senhor Rey...", cit., cap. CLIV, p. 808-809; Humberto Baquero - A Batalha ..., cit., vol. II, p. 762.

${ }^{90}$ MENDONÇA, Manuela - O Sonho da União Ibérica. Guerra Luso-Castelhana. 1475-1479. Matosinhos: Quidnovi, 2007, p. 27.

${ }^{91}$ Data apontada por Braamcamp Freire para a morte de D. Duarte de Meneses (FREIRE, Anselmo Braamcamp - Brasões..., cit., liv. terc., p. 281-282).

${ }^{92}$ ZURARA, Gomes Eanes de - Crónica do Conde D. Duarte de Meneses. Lisboa: Universidade Nova de Lisboa, 1978, cap. CLIIII, p. 350.

${ }^{93}$ CRUZ, Abel dos Santos - "O Rei e a Lança: História de uma campanha militar no Magrebe Ocidental (1463-1464)”, in Actas do IX Colóquio de História Militar. Os Militares na Sociedade Portuguesa. Lisboa: Comissão Portuguesa de História Militar, 1999, p. 86.

${ }^{94}$ DUARTE, Luís Miguel - “África”, in Nova História Militar de Portugal..., cit. vol. I, p. 428-429.

${ }^{95}$ ZURARA, Gomes Eanes de - Crónica do Conde D. Duarte..., cit., cap. CLIIII, p. 350 . 
Nuno Martins que lhe disponibilizou o seu cavalo. O escudeiro ali mesmo veio a morrer enquanto que $\mathrm{D}$. Duarte foi auxiliado a montar pelo conde de Monsanto. Todavia, o esforço de D. Álvaro de Castro foi em vão e pouco depois D. Duarte também veio a ser morto ${ }^{96}$.

O fracasso da campanha de 1463-1464 obrigou D. Afonso $\mathrm{V}$ a interromper as campanhas no Norte de África, pelo que só em 1471 o monarca decidiu levar a cabo nova incursão a Marrocos. Para saber a opinião do seu círculo próximo o monarca organizou "pratycas e conselhos em Lixboa nas casas do Conde de Monsanto". A princípio ficou explícita a vontade de atacar Tânger, mas como o conselho régio argumentou que no Reino não havia "soprimento" necessário para cercar e combater essa cidade, o monarca optou por Arzila. Esta cidade havia sido várias vezes espiada por Vicente Simões e Pero de Alcáçova, que, enquanto praticavam "fingidos negocios" com os mouros, tomavam notas de como se havia de ancorar e desembarcar, bem como de tudo o que era necessário para o assento em terra ${ }^{97}$.

Embora o comando supremo da expedição se deva a D. Afonso V, dois chefes teriam compartilhado a responsabilidade do cargo: D. Álvaro de Castro, conde de Monsanto, e D. João Coutinho, conde de Marialva. A 15 de Agosto a frota portuguesa partiu do Restelo rumo a Lagos. Depois de escala naquele porto, local onde as frotas de Lisboa e Porto se juntaram aos navios e homens do Algarve, Rui de Pina diz que os navios agrupados somavam um total de 477 velas e perto de trinta mil homens ${ }^{98}$. Todavia, estes números devem ser tomados com as devidas reservas ${ }^{99}$.

Chegando a Arzila no dia 20, só ao amanhecer do dia seguinte iniciou-se o desembarque. Porém, o mar bastante agitado e os recifes locais levaram ao naufrágio de uma galé, de caravelas e de batéis, acabando por levar à morte alguns 8 fidalgos e perto de 200 outros combatentes, entre cavaleiros e escudeiros pesadamente armados. Apenas ao terceiro dia, já com mais condições de segurança, o desembarque foi finalizado ${ }^{100}$. Pela manhã do dia

${ }^{96}$ ZURARA, Gomes Eanes de - Crónica do Conde D. Duarte..., cit., cap. CLIIII, p. 354 .

${ }^{97}$ PINA, Rui de - "Chronica do Senhor Rey...," cit., cap. CLXII, p. 818.

${ }^{98}$ PINA, Rui de - "Chronica do Senhor Rey...", cit., cap. CLXIII, p. 820.

${ }^{99}$ Sobre esta questão, vide a dúvida levantada por DUARTE, Luís Miguel - "África", in Nova História Militar de Portugal..., cit., vol. I, p. 429.

${ }^{100}$ PINA, Rui de - “Chronica do Senhor Rey...”, cit., cap. CLXIV, p. 820. 
24 de Agosto, D. Álvaro de Castro, a quem “a estancia e guarda do Castello era encomendada", mandou um recado a $\mathrm{D}$. Afonso $\mathrm{V}$ dizendo que o alcaide de Arzila queria chegar a um acordo com o monarca. Contudo, antes de D. Afonso $\mathrm{V}$ dar a sua resposta final, chegou a notícia de que as forças cristãs haviam penetrado na vila. Os mouros ofereceram resistência mas acabaram por se refugiar na mesquita e no castelo ${ }^{101}$. O rei ordenou então a D. Álvaro de Castro que ficasse de vigia à porta secreta do castelo (porta da traição) para que os mouros não fugissem, enquanto ele se encarregava do ataque à mesquita ${ }^{102}$, onde veio a morrer o conde de Marialva ${ }^{103}$. Terminada a peleja na mesquita, as forças portuguesas concentraram os seus esforços no castelo, local onde D. Álvaro de Castro viria a ser morto juntamente com outros nobres.

Embora Rui de Pina (145?-1522) ${ }^{104}$ não revele números, as mortes entre os soldados portugueses terão sido consideráveis e muitos nomes ficaram omissos (não permitindo assim perpetuar a honra e memória de muitos dos que morreram pelejando), razão pela qual Damião de Góis (1502-1574) e, de forma mais vincada, Duarte Nunes de Leão (c. 1530-1608), parecem insurgir-se contra o que o cronista escreveu ${ }^{105}$. Rui de Pina omite mesmo a forma como D. Álvaro de Castro morreu. Contudo, fazendo-se valer de testemunhos orais, Damião de Góis diz que a morte ocorreu quando o conde estava a acudir um mouro sitiado num cubelo. $\mathrm{O}$ mouro teria prometido que se D. Álvaro de Castro lhe salvasse a vida retribuiria com um grande resgate e, neste sentido, o conde subiu por uma escada aproveitando o mouro para

${ }^{101}$ PINA, Rui de - "Chronica do Senhor Rey...", cit., cap. CLXV, p. 821.

${ }^{102}$ GÓIS, Damião de - Crónica do Príncipe..., cit., cap. XXV, p. 68-69; LEÃO, Duarte Nunes de - "Crónica e Vida del Rey D. Affonso o V", Crónicas dos Reis de Portugal. Porto: Lello \& Irmão - Editores, 1975, cap. XXXIX, p. 903-904.

${ }^{103}$ PINA, Rui de - "Chronica do Senhor Rey...", cit., cap. CLXV, p. 821-822; GÓIS, Damião de-Crónica do Príncipe ..., cit., cap. XXV, p. 69; LEÃO, Duarte Nunes de - "Crónica e Vida...", cit., cap. XXXIX, p. 903-904.

${ }^{104}$ SERRÃO, Joaquim Veríssimo - Cronistas do século XV posteriores a Fernão Lopes, 2. ${ }^{a}$ ed. Lisboa: Instituto de Cultura e Língua Portuguesa, 1989, p. 53-54.

${ }^{105}$ GÓIS, Damião de - Crónica do Príncipe ..., cit., cap. XXVI, p. 70-71; LEÃO, Duarte Nunes de - "Crónica e Vida...", cit., cap. XXXIX, p. 904-905. Sobre estas questões, e para uma visão da construção do discurso cronístico perspectivada no campo das representações, vide VICENTE, Paulo - A Violência na Cronística sobre Marrocos nos séculos XV-XVI: representações e vivências. Dissertação de Mestrado em História dos Descobrimentos e da Expansão Portuguesa (FLUL): 2007. 
lhe cortar a cabeça num primeiro golpe. Todavia, Damião de Góis acrescenta que "alguns" referem que a morte foi provocada por uma seta perdida que atingiu a cabeça do conde quando este estava numa das torres do castelo sem o capacete posto ${ }^{106}$.

Diferente versão dos factos da batalha e da morte dos condes apresenta Bernardo Rodrigues (c. 1500-1560), soldado e autor contemporâneo de Damião de Góis que viveu de perto a realidade em Arzila e noutras praças de guerra marroquinas. Com efeito, Bernardo Rodrigues refere que o conde de Monsanto entrou a matar tudo e todos na mesquita não hesitando em cortar cabeças, braços e pernas de forma indiscriminada, acabando também por ser degolado ali mesmo ${ }^{107}$.

Theresa Schedel de Castello Branco, numa teoria curiosa, refere que parece ter "havido erro da parte de Ruy de Pina quanto à data em que morreu o conde D. Álvaro, porque existe um documento de 1469 pelo qual se constata que nesse ano, D. João, filho do conde de Monsanto, D. Álvaro, é empossado pelo rei em todos os bens de seu pai, sendo enviadas ordens para as justiças do Reino para que reconhecessem a autoridade de D. João. Ora isto é claramente indicativo de impossibilidade de administração, e decerto por doença, por parte do conde de Monsanto, D. Álvaro. Pelo que não seria provável que o mesmo tivesse combatido em Arzila em 1471, é antes muito provável que tenha morrido de doença por essa altura"108.

$\mathrm{O}$ argumento da autora baseia-se apenas na informação contida num documento de 1469 - o qual não é referido, mas que temos poucas dúvidas de que se trata de uma carta de 8 de Dezembro deste ano -, faltando o estudo de outra documentação relativa a D. Álvaro de Castro e a D. João de Castro.

${ }^{106}$ GÓIS, Damião de - Crónica do Príncipe..., cit., cap. XXVI, p. 69-70. Cristóvão Alão de Morais (1632-1693), seguido por outros genealogistas, diz também que a morte foi causada por uma seta que lhe atingiu a cabeça (MORAIS, Cristóvão Alão de - Pedatura Lusitana..., cit., p. 111; ANDRADE, Ferreira de, Cascais..., cit., p. 50). Cristóvão Alão de Morais, fantasiando esta questão, acrescenta que uma índia havia visualizado que se D. Álvaro de Castro fosse a Arzila não retornaria com vida, pelo que D. Afonso V não quis que o conde de Monsanto participasse naquela expedição. Porém, e ainda de acordo com o mesmo genealogista, o conde não deu crédito ao que havia sido dito.

${ }^{107}$ RODRIGUES, Bernardo - Anais de Arzila, t. I. Lisboa: Academia das Sciências de Lisboa, 1915, p. 98; VICENTE, Paulo - A Violência na Cronística ..., cit., p. 213-214.

${ }^{108}$ Cfr. BRANCO, Theresa Schedel de Castello - Os Painéis de S. Vicente de Fora. As Chaves do Mistério. Lisboa: Quetzal Editores, 1994, p. 51 (n. 1) e 195. 
É verdade que esta carta de 1469 mostra que D. Afonso V ordenava que certos bens, títulos e ofícios de D. Álvaro de Castro - por consentimento do próprio - passassem para D. João de Castro, mas isto teria efeito somente após a morte de D. Álvaro. Portanto, não era algo para ocorrer de imediato. A carta não revela qualquer estado de doença por parte do conde de Monsanto, sendo que o rei parece ter agido por vontade própria ${ }^{109}$, se bem que com consentimento de D. Álvaro de Castro e da sua mulher.

Para além disso, existindo documentação que nos revela que D. Álvaro de Castro ainda estava vivo em 1471, resta-nos saber se participou ou não na expedição a Arzila. Conforme foi referido anteriormente, existe uma carta concedida a D. Álvaro de Castro datada de 25 de Julho de 1471, um mês antes da tomada de Arzila, na qual D. Afonso V atribuiu-lhe uma tença anual de 28.571 reais brancos. Contudo, a ordem era para que o conde começasse a usufruir dessa tença apenas a partir de 1 de Janeiro de $1472^{110}$. Se o conde estivesse gravemente doente e impossibilitado de dar o seu contributo em Arzila, vislumbrando-se ainda que o seu possível estado de doença poderia levá-lo brevemente à morte, teria o rei concedido tal tença para que D. Álvaro de Castro começasse a recebê-la apenas a partir do ano seguinte? Aliás, numa carta de 1497 em que é confirmada a mercê de fronteiro-mor de Lisboa e seu termo (concedida ainda no reinado D. Afonso V e confirmada pelo príncipe D. João) a D. Rodrigo de Castro, fidalgo do conselho do rei, alcaide-mor da Covilhã e filho de D. Álvaro de Castro, é referido que o conde de Monsanto "morreo em a filhada da nosa vila d'arzila" 111 . Portanto, não restará dúvida de que o conde morreu naquela praça africana, sendo

109 “nos de nosso moto proprio E çerta siençia com acordo do prinçipe dom Joham meu sobre todos mujto preçado E amado filho ssem elle nem outro por elle nollo pedijr. / Teemos por bem $\mathrm{E}$ nos praz queremos $\mathrm{E}$ mandamos que per falleçimento do comde de monssanto seu padre o dicto dom Joham aJa logo o dicto condado de monssanto E titullo delle E sse chame logo comde do dicto condado de monssanto [...]" (Instituto Arquivos Nacionais/Torre do Tombo (Lisboa), Chancelaria de D. Afonso V, liv. 16, fl. 118). Embora este e outros dois documentos (vide supra, n. 63, infra, n. 111) tenham sido transcritos para serem anexados no final, a extensão algo longa deste estudo acabou por fazer com que não os colocássemos.

${ }^{110}$ Vide supra, n. 38.

${ }^{111}$ Instituto Arquivos Nacionais/Torre do Tombo (Lisboa), Chancelaria de D. Manuel I, liv. 28 , fls. $6 \mathrm{v}-7$. 
que num momento posterior o seu corpo terá sido trazido para Portugal, desembarcado em Cascais e sepultado na Penha Longa ${ }^{112}$.

Embora D. Afonso V pareça ter agido por vontade própria, sem referir qual o motivo que o levou a ordenar que certos bens, títulos e ofícios do D. Álvaro de Castro passassem para D. João de Castro, fê-lo após consultar o conde e a condessa de Monsanto, D. Isabel (m. 1482). O monarca e o conde eram bastante chegados, pelo que deverá ter havido um gesto por parte de D. Afonso $\mathrm{V}$ no intuito de reconhecer toda uma vida de serviço à Coroa e de assegurar que essas terras, títulos e ofícios provenientes do esforço e feitos do conde continuassem na sua linhagem após a sua morte.

Seja como for, a morte de D. Álvaro de Castro, fidalgo muito próximo de D. Afonso V, foi muito sentida "porque certo elle no campo e na Corte, na paz e na guerra era por seu siso, discryçam, e esforço homem muy principal" 113 . Para D. Álvaro de Castro chegavam ao fim mais de 34 anos de serviço militar à Coroa portuguesa em várias frentes, morrendo em combate tal como o seu pai e um dos seus filhos. Contudo, ao contrário de muitos combatentes que morreram anónimos e sem reconhecimento do seu valor, o senhor de Cascais teve a graça de a cronística o eternizar. Aliás, D. Álvaro de Castro, tal como D. João Coutinho, conde de Marialva, poderá mesmo ter tido a honra de figurar nos Painéis de S. Vicente de Fora ${ }^{114}$.

${ }^{112}$ De acordo com Ferreira de Andrade, D. Álvaro de Castro foi sepultado na capela-mor da Penha Longa (Sintra). Ali mesmo existe um cenotáfio onde, traduzindo do latim, se pode ler: «Debaixo desta breve lápida, dedicada à Mãe de Deus, estão sepultados os gloriosos restos mortais de D. Álvaro de Castro, $1 .^{\circ}$ Conde de Monsanto e de sua esposa Isabel, de cuja real estirpe e bondade muitas coisas por muitos foram escritas» (ANDRADE, Ferreira de - Cascais..., cit., p. 50 e 75 (n. 38)).

${ }^{113}$ PINA, Rui de - "Chronica do Senhor Rey...", cit., cap. CLXV, p. 821-822.

${ }^{114}$ D. Álvaro de Castro e D. João Coutinho (cf. FONSECA, António Belard da O Mistério dos Painéis, 2. ${ }^{\text {a }}$ ed. Lisboa: [s.n.], 1963, p. 157-158; MATOS, José Sarmento deA Invenção de Lisboa, liv. II - As Vésperas. Lisboa: Temas e Debates, 2009, p. 484), tal como D. João de Castro, filho primogénito de D. Álvaro de Castro e futuro conde de Monsanto (cf. BRANCO, Theresa Schedel de Castello - Os Painéis..., cit., p. 55, 189 e 195), têm sido identificados como possíveis figurantes nos Painéis de São Vicente de Fora, embora as suas pessoas sejam atribuídas a diferentes figuras, isto consoante as interpretações dos diversos autores. Para além disso, existe uma pintura no Museu de Vaduz (Liechtenstein), datada de 1456, que se reporta a um cavaleiro desconhecido e que José dos Santos Carvalho pensa ser D. Álvaro de Castro. A pintura teria sido feita por Nuno Gonçalves em colaboração com João Anes (cf. CARVALHO, José dos Santos - Iconografia e Simbólica do Políptico de São Vicente de Fora. Lisboa: Edição do Autor, 1965, p. 297 e 303). 


\section{D. Álvaro de Castro e o frete de navios}

Pela altura da conquista de Ceuta, ao contrário do que por vezes se pensa, a produção cerealífera em Marrocos poderia estar numa fase de enfraquecimento de tal modo que, em 1414, os Portugueses venderam trigo em Fez ${ }^{115}$. Era a partir do Reino que se abastecia Ceuta, cuja guarnição era composta por cerca de dois mil e quinhentos homens, ainda que "com fruste auxílio da zona da Tarifa e Cádis" ${ }^{116}$. Dos vários recursos que D. João I mandou apropriar para a governança desta praça contam-se várias lezírias no Ribatejo, campos de trigo no Alentejo ${ }^{117}$, bem como os sáveis pescados nas avargas do rio Tejo e outros numerosos rendimentos cobrados nos diversos almoxarifados do Reino ${ }^{118}$.

Com o desenrolar do século XV assiste-se ao envolvimento do chamado cavaleiro-mercador ${ }^{119}$ nos negócios de abastecimento das praças de guerra africanas, situação à qual D. Álvaro de Castro não escapou. Por uma carta de quitação de 1 de Maio de 1456, referente às "cousas" de Ceuta despendidas entre 1451-1452, ficamos a saber que D. Álvaro de Castro era dono de uma

${ }^{115}$ GASPAR, Maria Teresa Rabaça - A Circulação de Cereais entre Portugal e o Norte de África no século $X V$. Dissertação de Mestrado em História dos Descobrimentos e da Expansão Portuguesa (FLUL): 1997, p. 30. Com base num contrato firmado entre D. João I e uma companhia de cinco mercadores portugueses e três genoveses, garantia-se o abastecimento de Ceuta entre 1423-1424 com trigo vindo de Castela, da Sicília e de outras partes (cf. GODINHO, Vitorino Magalhães - Os Descobrimentos e a Economia Mundial, 2. ed., vol. III. Lisboa: Editorial Presença, 1982, p. 248).

${ }^{116}$ FARINHA, António Dias - Portugal e Marrocos..., cit., vol. I, p. 186. Todavia, devido às dificuldades de abastecimento provocadas pela resistência moura, também se recorria a uma política de saque que visava atenuar a situação (cf. CRUZ, Abel dos Santos "As Almogaverias em Marrocos", in Actas do VI Colóquio de História Militar. Portugal na História Militar. Lisboa: Comissão Portuguesa de História Militar, 1995, p. 115-116).

${ }^{117} \mathrm{Em}$ 1442, Ceuta recebeu 1.920 alqueires de trigo; nos anos de 1451 e 1452 foram embarcados, em Mértola, 241 moios de trigo provenientes das colheitas do Sul do Alentejo para aquela praça (GODINHO, Vitorino Magalhães - Os Descobrimentos..., cit., vol. III, p. 248-249).

${ }^{118}$ FARINHA, António Dias - Portugal e Marrocos ..., cit., vol. I, p. 194. Antes de 1438 já havia um armazém próprio em Lisboa, em casas pertencentes ao Município, que guardava as provisões destinadas a Ceuta (MENESES, José de Vasconcellos e-Armadas Portuguesas. De meados do século XIV a meados do século XVI. Alimentação e abastecimento. [s.1.]: Editorial Resistência, 1980, p. 14; GODINHO, Vitorino Magalhães - Os Descobrimentos..., cit., vol. III, p. 248-249).

${ }^{119}$ Vide infra, n. 136 e 137. 
barca que levava trigo, cevada e pão para aquela praça. Com efeito, em 1452 foram entregues 103 moios, 24 alqueires de trigo e 6 moios e 16 alqueires de cevada a Luís de Deus, morador em Lisboa e mestre da barca de D. Álvaro de Castro, para transportar até Ceuta ${ }^{120}$. Foram disponibilizados ainda 621.5 reais para compra de 8 dúzias "desteiras”, de 9 dúzias "destiba" e de 50 pregos para o telhado da dita barca ${ }^{121}$.

Outra carta de quitação, desta vez de 2 de Março de 1456, relativamente às despesas feitas entre 1453-1454, revela-nos outros produtos que entravam nestas viagens. É referido que foram entregues 576 reais a Antão Martins Caiado, "arrumador que avya daver por quaremta e oito tonees de vynho e carnes e augua que arumou na naoo que foy de Pero Vydall quamdo foy dom Alvoro [de Castro] e dom Garcia e dom Fernando e Alvoro Faria quamdo foram a Cepta" ${ }^{122}$. Para além disso, a referida carta de quitação menciona que D. Álvaro de Castro recebeu 648 alqueires de trigo, 450 almudes de vinho, 11 cascos de tonéis, 2 soas de carne, 4 pipas, 24 lixas, vinte e quatro raias, 1.332 cavalas e 13.150 reais de soldo e mantimento de dois meses para si, 50 escudeiros e besteiros e 15 homens de pé que levou para Ceuta ${ }^{123}$.

Para estes casos ocorridos entre 1451-1454 nada é referido quanto a uma possível contribuição de Cascais em alimentos, nem que o embarque de produtos fosse feito no porto daquela vila. Todavia, Manuel A. P. Lourenço - sem aduzir provas - indica que, em 1451, Cascais já fazia "largo comércio com Ceuta" 124 e que, para "além das suas ocupações na corte do rei e na sua própria, na vila [...]”, D. Álvaro de Castro "possuía uma barca que fazia constantes viagens àquela cidade africana, levando víveres e munições, com o que o comércio de Cascais muito lucrava"125. Manuel A. P. Lourenço chega mesmo a dizer que "pelo fim do século XV, com o desenvolvimento

${ }^{120}$ AZEVEDO, Pedro de - Documentos ..., cit., t. II, p. 348.

${ }^{121}$ AZEVEDO, Pedro de - Documentos ..., cit., t. II, p. 350.

${ }^{122}$ AZEVEDO, Pedro de - Documentos ..., cit., t. II, p. 684-685.

${ }^{123}$ Segundo consta, em 1454, já no seu regresso, D. Álvaro de Castro entregou 5 cascos de tonéis e 4 cascos de pipas "que trouue de çepta" ao tesoureiro-mor das coisas de Ceuta em Lisboa (AZEVEDO, Pedro de - Documentos..., cit., t. II, p. 688 e 703; MARQUES, João Martins da Silva - Descobrimentos ..., cit., sup. vol. I, p. 353, doc. 228).

${ }^{124}$ LOURENÇO, Manuel A. P. - "História de Cascais e do seu Concelho", A Nossa Terra, 72 (1954) 2.

${ }^{125}$ LOURENÇO, Manuel A. P. - "História de Cascais...”, cit., 75 (1954) 2. 
do comércio para a África, se impôs o alargamento de Cascais para norte e para leste" 126 .

Estas afirmações de Manuel A. P. Lourenço merecem uma análise cuidada da nossa parte. Ora, sabemos que D. Álvaro de Castro tinha uma barca, aliás, até tinha outros navios para frete que andavam nas lides comerciais, e que de Cascais sairiam alimentos para o abastecimento de Ceuta, mas as fontes não revelam que a barca do senhor de Cascais rumava a Ceuta por existirem ligações comerciais específicas entre os dois locais. Como noutros casos, pelo seguimento de ideias e informações fornecidas por Manuel A. P. Lourenço, dá para perceber que o mesmo se inspirou nas fontes publicadas por Pedro de Azevedo. Porém, o que a documentação publicada por este último investigador deixa perceber é que D. Álvaro de Castro era proprietário de uma barca que fazia o transporte de produtos para Ceuta, sendo que o próprio embarcava frequentemente para aquela praça com forças militares destacadas para servirem à sua ordem. É sabido que muitos "negociantes e homens de cabedais concorriam aos contratos de abastecimento das praças" marroquinas ${ }^{127}$, o que poderá ter sido o caso do senhor de Cascais. Presume-se, neste seguimento, que D. Álvaro de Castro tivesse um contrato para abastecimento de Ceuta, sendo que os seus navios transportariam produtos de diversas proveniências embarcados em Lisboa, local onde se aprestavam as armadas, não se conhecendo uma ligação específica à vila de Cascais, apesar de esta também contribuir com produtos dos seus solos para o abastecimento ceptense ${ }^{128}$.

Aliás, as fontes não revelam qualquer proveito marítimo que D. Álvaro de Castro possa ter tirado pelo facto de dominar uma vila portuária às portas de Lisboa, ainda que Cascais pudesse ter servido de base naval das suas plataformas de transporte e de apoio aos seus negócios ${ }^{129}$. Assim sendo,

${ }^{126}$ LOURENÇO, Manuel A. P. - "História de Cascais...", cit., 76 (1954) 2.

${ }^{127}$ FARINHA, António Dias - Portugal e Marrocos..., cit., vol. I, p. 21.

${ }^{128}$ Por intermédio de uma carta de quitação de 12 de Julho de 1443 , na qual é referida o que recebeu e despendeu o tesoureiro das coisas de Ceuta entre 1 de Janeiro de 1440 e 1 de Janeiro de 1442, menciona-se que, tal como Lisboa e Sintra, Cascais era uma das regiões que fornecia peixe a Ceuta (cf. MARQUES, João Martins da Silva-Descobrimentos ..., cit., sup. vol. I, p. 523, doc. 951).

${ }^{129}$ Ferreira de Andrade já havia questionado se o tráfego marítimo dos navios de D. Álvaro de Castro seria feito através do porto de Cascais (cf. ANDRADE, Ferreira de - Cascais..., cit., p. 74 (n. 27)). 
estas questões têm de ser vistas sob a forma de hipótese e não como dados adquiridos. Não podem ser vistas nem transmitidas como se fossem factos históricos ${ }^{130}$.

Foi entre 1440 e 1471 que D. Álvaro de Castro senhoriou Cascais. Este fidalgo também estava ligado ao frete de navios que tinham como destino a Flandres. Sabe-se que era proprietário das naus Bretoa (cujo mestre era Luís de Deus) e Ingresa (da qual era mestre João Cão, possível familiar de Diogo Cão) ${ }^{131}$, fretadas para o tráfico com o Norte da Europa, o grande abastecedor de armamento de Portugal, muito embora este também fosse procurado "com avidez [...] nos portos mediterrânicos"132. Entre 1441 e 1443 ambas as naus estiveram em Bruges, principal centro de comércio do Norte europeu nos séculos XIV e XV, e outras partes do condado da Flandres. Numa delas, já no regresso a Portugal e entre vários materiais que deverá ter transportado, ficou registado o transporte de pólvora (15 quintais em 2 botas), arneses compridos com "barretas e baueiras" (10), arneses de pernas (5 pares), bem como de bombardas de duas (2) e três câmaras (3) encaixadas em madeira, tudo com destino ao armazém de Lisboa ${ }^{133}$. É muito provável que este armamento vindo na nau de D. Álvaro de Castro, juntamente com semelhantes exemplares e outros tipos de armamentos vindos noutros navios, fosse para, posteriormente, abastecer os soldados portugueses em Ceuta.

${ }^{130}$ Ferreira de Andrade chegou a levantar dúvidas quanto às afirmações categóricas proferidas por Manuel A. P. Lourenço sem apoio em qualquer base documental, mais concretamente no que respeita à destruição que os terramotos de 1356 e 1404 teriam causado em Cascais, ainda que de forma ligeira (cfr. ANDRADE, Ferreira de $-A$ Vila de Cascais e o Terremoto de 1755, 2. . ed. Cascais: Câmara Municipal de Cascais, 1964, p. 52 (n. 53) [1. ${ }^{\mathrm{a}}$ ed., 1956]).

${ }^{131}$ Cf. FONSECA, Quirino da - Os Portugueses no Mar. Memórias Históricas e Arqueológicas das Naus de Portugal, 2. ${ }^{\text {a }}$ ed. Lisboa: Comissão Cultural da Marinha, 1989, p. 117; MARQUES, A. H. de Oliveira - Notas para a História da Feitoria Portuguesa na Flandres, no século XV, sep. de Studi in onore di Amintore Fanfani, vol. 2. Milano: A. Giuffrè, 1962, p. 470 (n. 127).

${ }^{132}$ BARATA, Filipe Themudo - Navegação, Comércio e Relações Politicas: os Portugueses no Mediterrâneo Ocidental (1385-1466). [Lisboa]: Fundação Calouste Gulbenkian, [1998] p. 28.

${ }^{133}$ FREIRE, Anselmo Braamcamp - "Maria Brandoa, a do Crisal", in Archivo Historico Portuguez, vol. VI. Lisboa: Officina Typographica - Calçada do Cabra, 1908, p. 350-351; MARQUES, João Martins da Silva - Descobrimentos ..., cit., vol. I, p. 428 e 432, doc. 337. 
Se já tínhamos referido que, em 1452, Luís de Deus, mestre da barca de D. Álvaro de Castro, transportava alimentos para Ceuta, agora vimos que logo nos inícios da década de 1440 já era mestre de uma das naus que foram a Bruges buscar armamento. Portanto, fica notório que D. Álvaro de Castro era proprietário de navios para frete que buscavam no Norte da Europa armamentos necessários ao abastecimento das praças de guerra marroquinas e que, juntamente com outros produtos alimentares, seriam embarcados rumo ao seu destino. O senhor de Cascais não teria interferência directa no carregamento dos navios, apenas proporcionaria transporte mediante pagamento.

É verdade que em muitos casos o frete dos navios que rumavam a África surgia associado a embarcações estrangeiras, o que "significava também automaticamente o recrutamento de tripulações e a obtenção de determinadas mercadorias, que colmatavam as faltas em Portugal"134, mas os navios nacionais eram igualmente fretados para as expedições de socorro e abastecimento a Marrocos ${ }^{135}$. Este é, aliás, o tempo do cavaleiro-mercador que se lança no comércio internacional e ultramarino como armador ou até mesmo como capitão de navios, fazendo face à concorrência dos mercadores estrangeiros que negoceiam em Lisboa e que se ligam "ao comércio de grosso trato com os países europeus"136. De facto, se a nobreza estava quase exclusivamente envolvida nas actividades militares, com o desenrolar do século XV os valores, posições sociais e as condutas vão alterar-se. Os mercadores passam a pretender foros de cavalaria enquanto que os cavaleiros se dedicam cada vez mais ao corso, assaltos a aldeias mouras, à navegação e ao comércio. É o tempo do mercador-cavaleiro e do cavaleiro-mercador ${ }^{137}$.

${ }^{134}$ LIMÃO, Paula - Portugal e o Império Turco na área do Mediterrâneo (século XV). Dissertação de Mestrado em História dos Descobrimentos e da Expansão Portuguesa (FLUL), vol. I: 1994, p. 182.

${ }^{135} \mathrm{O}$ próprio D. Duarte de Meneses, cunhado de D. Álvaro de Castro, tinha navios para frete que andavam no abastecimento de Ceuta (cf. AZEVEDO, Pedro de - Documentos..., cit., t. II, p. 346).

${ }^{136}$ MORENO, Humberto Baquero - "Ritmos de desenvolvimento da sociedade portuguesa nos séculos XIV e XV", Marginalidade e Conflitos Sociais em Portugal nos Séculos XIV e XV. Estudos de História. Lisboa: Editorial Presença, 1985, p. 14-15.

${ }^{137}$ GODINHO, Vitorino Magalhães - "Complexo histórico-geográfico", in SERRÃO, Joel (dir.), Dicionário de História de Portugal, vol. I. Lisboa: Iniciativas Editoriais, 1971, 
Proprietário de 1 barca, de 1 caravela e de 2 naus, teria D. Álvaro de Castro outros navios? Estariam os navios referidos envolvidos somente na actividade de frete para transporte de combatentes, alimentos e armamento? Para além de Ceuta e Flandres, os seus navios tiveram outros destinos? A participação da sua caravela numa expedição à costa ocidental africana (1445) foi um caso excepcional, ou o envolvimento dos seus navios teria outra frequência neste tipo de viagens? Estas, entre outras, são questões que precisam de ser melhor compreendidas.

\section{Conclusão}

Sempre ligado a grandes acontecimentos da história nacional, D. Álvaro de Castro serviu nas campanhas militares a Marrocos desde Tânger a Arzila e prestou outros valiosos serviços à Coroa, vindo a ser recompensando gradualmente através de um vasto rol de benefícios, dignidades e ofícios. Não se pode esquecer igualmente as isenções e privilégios que abarcaram vários dos seus subordinados - os quais as crónicas não registam -, combatentes que partiram de várias terras ligadas a D. Álvaro rumo ao desconhecido, acabando por ficar feridos, cativos ou morrer anonimamente. Além disso, são vários os documentos que nos dão conta de diversas viagens a solo ceptense onde D. Álvaro de Castro serviu e comandou forças militares portuguesas. De futuro, havendo espaço para desenvolver um estudo de carácter mais problematizante, é importante que se tente compreender melhor como se desenrolaram estas ligações e o serviço de D. Álvaro em Ceuta.

p. 646; GODINHO, Vitorino Magalhães - "Inovação e permanências nos séculos XV e XVI - entre mito e utopia", Mito e Mercadoria, Utopia e Prática de Navegar. Séculos XIII-XVIII. Lisboa: Difel, 1990, p. 96. "Os mercadores dos séculos XIV e XV não se limitavam, em geral, a comprar para vender a retalho, especificamente a comprar panos por grosso para revender a côvados, mas exerciam simultaneamente outras actividades: lavradores, arrematantes das rendas reais, do clero e dos nobres, funcionários da coroa (feitores, vedores da fazenda, almoxarifes, escrivães, administradores de nau), mestres de navio, cambadores, fretadores, senhorios de nau, pescadores (armadores de pesca)" (cf. COELHO, António Borges - "Mercadores portugueses nos séculos XIV e XV", Questionar a História - II..., cit., p. [25]). 
Porém, a actividade de D. Álvaro de Castro foi mais complexa, não se resumiu aos feitos guerreiros. Na verdade, D. Álvaro de Castro parece enquadrar-se na figura do cavaleiro-mercador surgido com o advento de um novo complexo histórico-geográfico e que se vai estruturando ao longo de Quatrocentos. Os seus navios fretados rumavam ao Norte da Europa, onde buscavam armamento, bem como abasteciam Ceuta com variados produtos. Esperamos que, neste campo, a actividade de D. Álvaro de Castro também venha a ser melhor aclarada, se bem que nos pareça uma tarefa que pode vir a ser complicada já que os documentos de carácter económico ligados a este fidalgo, comparando com os de carácter militar, são mais escassos.

Não menos importantes são as ligações familiares vistas inicialmente e que, de futuro, terão igualmente que ser exploradas. 